INTERNATIONAL MONETARY FUND

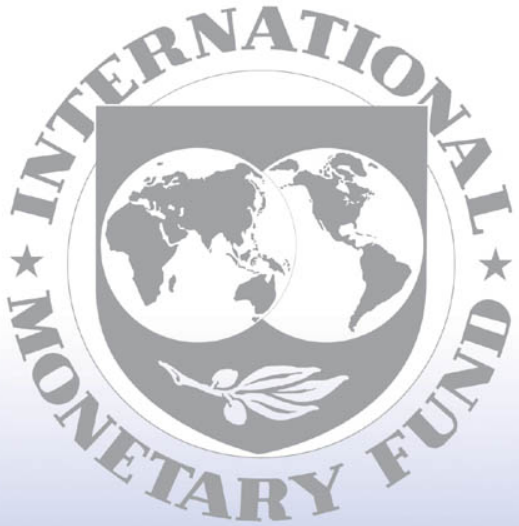

Staff

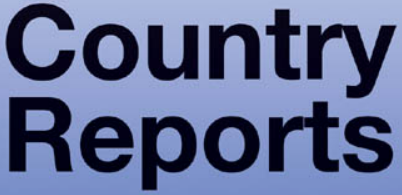




\section{Ireland: 2006 Article IV Consultation-Staff Report; Staff Supplement; and Public Information Notice on the Executive Board Discussion}

Under Article IV of the IMF's Articles of Agreement, the IMF holds bilateral discussions with members, usually every year. In the context of the 2006 Article IV consultation with Ireland, the following documents have been released and are included in this package:

- the staff report for the 2006 Article IV consultation, prepared by a staff team of the IMF, following discussions that ended on May 17, 2006, with the officials of Ireland on economic developments and policies. Based on information available at the time of these discussions, the staff report was completed on June 27, 2006. The views expressed in the staff report are those of the staff team and do not necessarily reflect the views of the Executive Board of the IMF.

- $\quad$ a staff supplement of July 18, 2006, updating information on recent developments.

a Public Information Notice (PIN) summarizing the views of the Executive Board as expressed during its July 26, 2006 discussion of the staff report that concluded the Article IV consultation.

The document listed below has been or will be separately released.

Financial System Stability Assessment Update

The policy of publication of staff reports and other documents allows for the deletion of market-sensitive information.

To assist the IMF in evaluating the publication policy, reader comments are invited and may be sent by e-mail to publicationpolicy@imf.org.

Copies of this report are available to the public from

International Monetary Fund $\bullet$ Publication Services

$70019^{\text {th }}$ Street, N.W. $\bullet$ Washington, D.C. 20431

Telephone: (202) 623-7430 • Telefax: (202) 623-7201

E-mail: publications@imf.org •Internet: http://www.imf.org

Price: $\$ 15.00$ a copy

International Monetary Fund

Washington, D.C. 
This page intentionally left blank 
INTERNATIONAL MONETARY FUND

\section{IRELAND}

\section{Staff Report for the 2006 Article IV Consultation}

Prepared by the Staff Representatives for the 2006 Consultation with Ireland Approved by Ajai Chopra and G. Russell Kincaid

June 27, 2006

- The Article IV consultation discussions were held in Dublin during May 10-17, 2006. The mission comprised Mr. Morsink (head), Ms. Iakova, and Ms. Moreno Badia (all EUR). Mr. O'Brien (MFD) participated for a few days in connection with the FSAP Update. The mission met with the Minister for Finance, the Governor of the Central Bank, the Chief Executive Officer of the Financial Regulator, other senior government officials, and representatives from labor and business organizations, financial institutions, and research institutes. Mr. Charleton (OED) attended most meetings.

- A coalition government has been in power since mid-1997 and was re-elected in mid-2002. General elections must take place by mid-2007.

- Ireland has accepted the obligations under Article VIII, Sections 2,3, and 4, and maintains an exchange system free of restrictions on payments and transfers for current international transactions, other than restrictions notified to the Fund under Decision No. 144-(52/51). 
Executive Summary

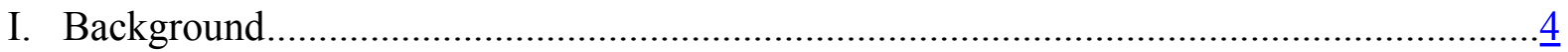

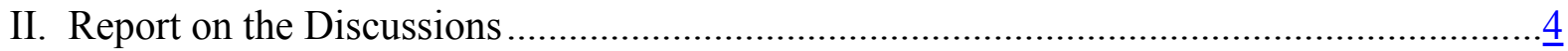

A. Outlook: Sunny in the Short Term but Clouds on the Horizon.............................. 4

B. Financial Stability: Rapid Credit Growth Implies Risks .......................................

C. Fiscal Policy: Preparing Cushions and Achieving Social Priorities.....................11

D. Wage Policy: Flexibility and Competitiveness ………......................................14

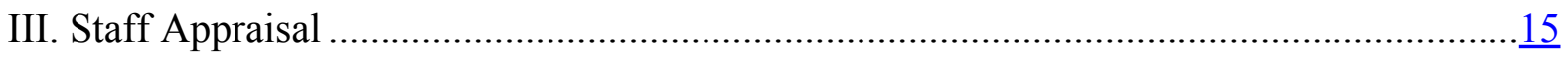

Tables

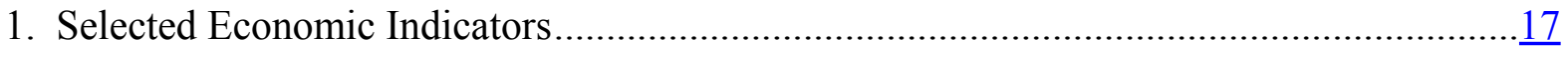

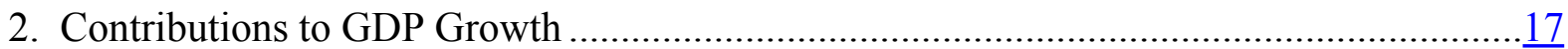

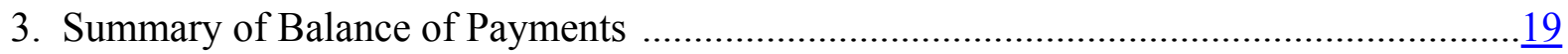

4. Indicators of External and Financial Vulnerability ......................................................19



Figures

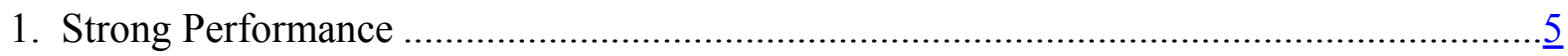



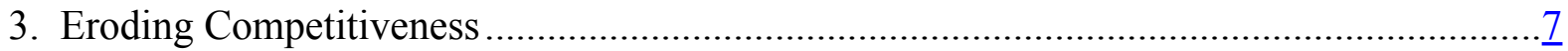




\section{EXECUTIVE SUMMARY}

Background: Economic performance remains strong, assisted by good policies. However, growth has become heavily reliant on building investment and competitiveness has eroded. The share of the construction sector in GDP is high and likely to fall over the next few years. Rapid growth could lead to overheating and wage pressures, which would further undermine competitiveness. Ireland is also vulnerable to external shocks.

Key Policy Issues: With strong but unbalanced growth in prospect, policies should encourage rebalancing and prepare cushions for the risk of a hard landing:

- The FSAP Update found that the financial system continues to perform well, but rapid credit growth is a vulnerability. The strengthening of the regulatory and supervisory framework is welcome and should continue, especially for insurance.

- Fiscal policy has been prudent. For 2007, staff recommends modest fiscal tightening, given the need to dampen aggregate demand, build a cushion against the risk of a hard landing, and prepare for population aging.

- Continued wage moderation and labor market flexibility are essential to support competitiveness. 


\section{BACKGROUND}

1. Ireland's economic performance remains strong (Figure 1). In recent years, real GNP growth was one of the highest among industrial countries; the unemployment rate was among the lowest; and HICP inflation declined to close to the euro area average. Employment growth was rapid, reflecting strong immigration and rising labor force participation. This remarkable performance reflected both good policies and fortunate circumstances. Economic policies have been in line with Fund policy advice: prudent government spending led to declining government debt; low taxes on labor and business income encouraged labor supply and investment; and flexible labor and product markets helped growth. At the same time, favorable demographics boosted the working-age population, and participation in EMU lowered interest rates.

\section{However, economic activity has become reliant on building investment and} competitiveness has eroded (Figures 2 and 3). The share of the construction sector in economic activity has increased and is now one of the highest in Europe. Bank credit to property-related sectors has grown rapidly and now accounts for more than half of total bank lending. Household debt as a share of household disposable income rose to about 130 percent in 2005, among the highest in Europe. Reflecting the expansion of the labor-intensive construction and services sectors, labor productivity growth has declined. The combination of the slowdown in productivity growth, faster wage growth in Ireland compared to its trading partners, and the appreciation of the euro, has led to an appreciation of the ULCbased real effective exchange rate. Partly as a result, the contribution of net exports to growth has fallen steadily since 2001. After being in balance for several years, the external current account registered a deficit of about 2 percent of GDP in 2005.

\section{As agreed with the authorities, this year's Article IV consultation is}

streamlined. The focus is on financial stability (building on the concurrent FSAP Update), fiscal policy, and wage policy. This staff report and the FSAP Update paper are the only documentation for the consultation.

\section{REPORT ON THE DISCUSSIONS}

\section{A. Outlook: Sunny in the Short Term but Clouds on the Horizon}

4. The authorities and staff agreed that economic growth is likely to be strong in the short term (Table 1). Staff project real GNP growth in 2006-07 of about 51/2 percent, driven by private consumption, in turn boosted by strong employment and income growth, and maturing Special Saving Incentive Accounts. Business investment is expected to remain robust, reflecting continued low interest rates and the strength of the global economy. In line with the re-acceleration of house prices since mid-2005, residential investment is likely to 
Figure 1. Strong Performance
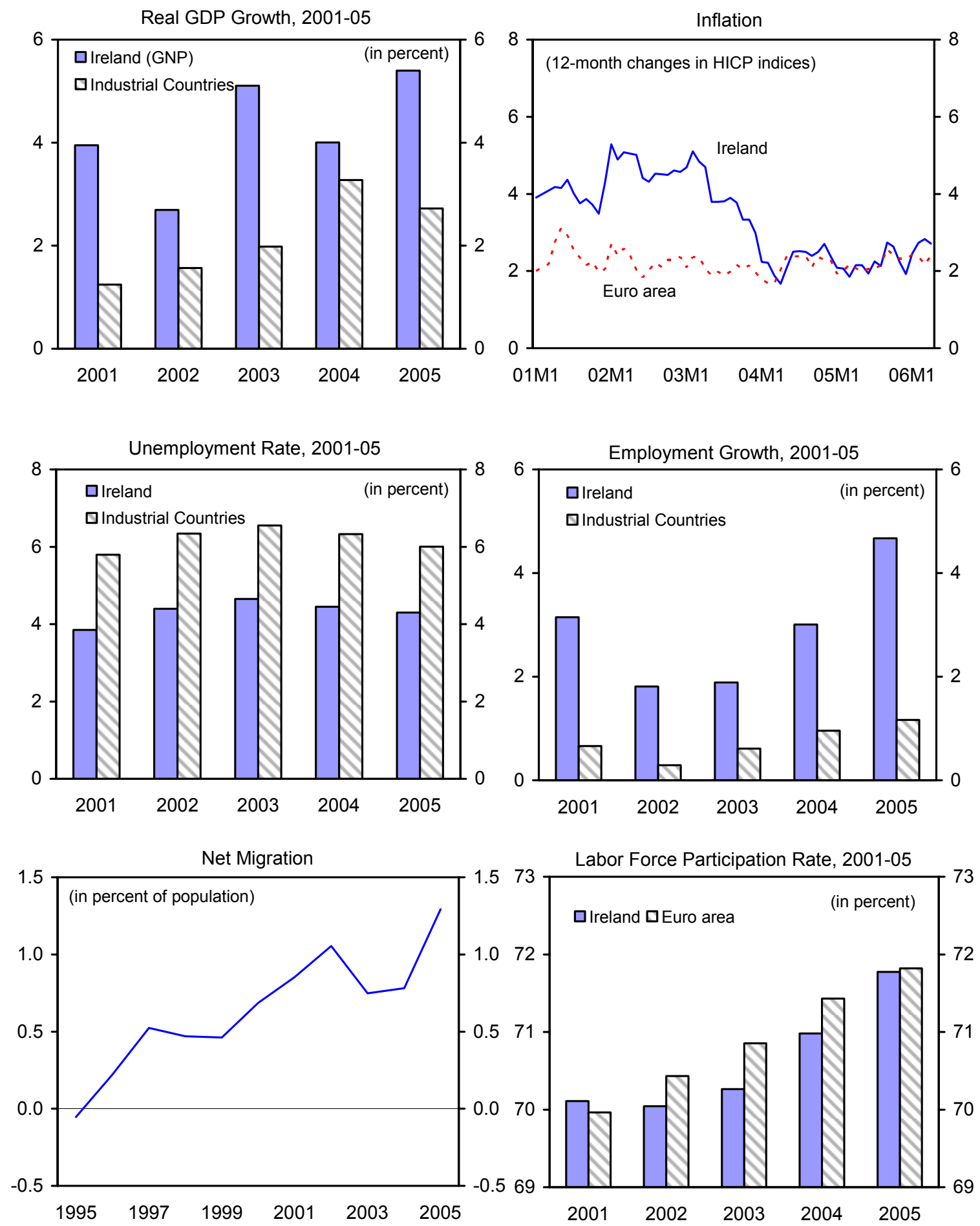

Sources: Central Statistics Office, Haver Analytics, OECD, and IMF: World Economic Outlook. 
Figure 2. Heavy Reliance on Building Investment
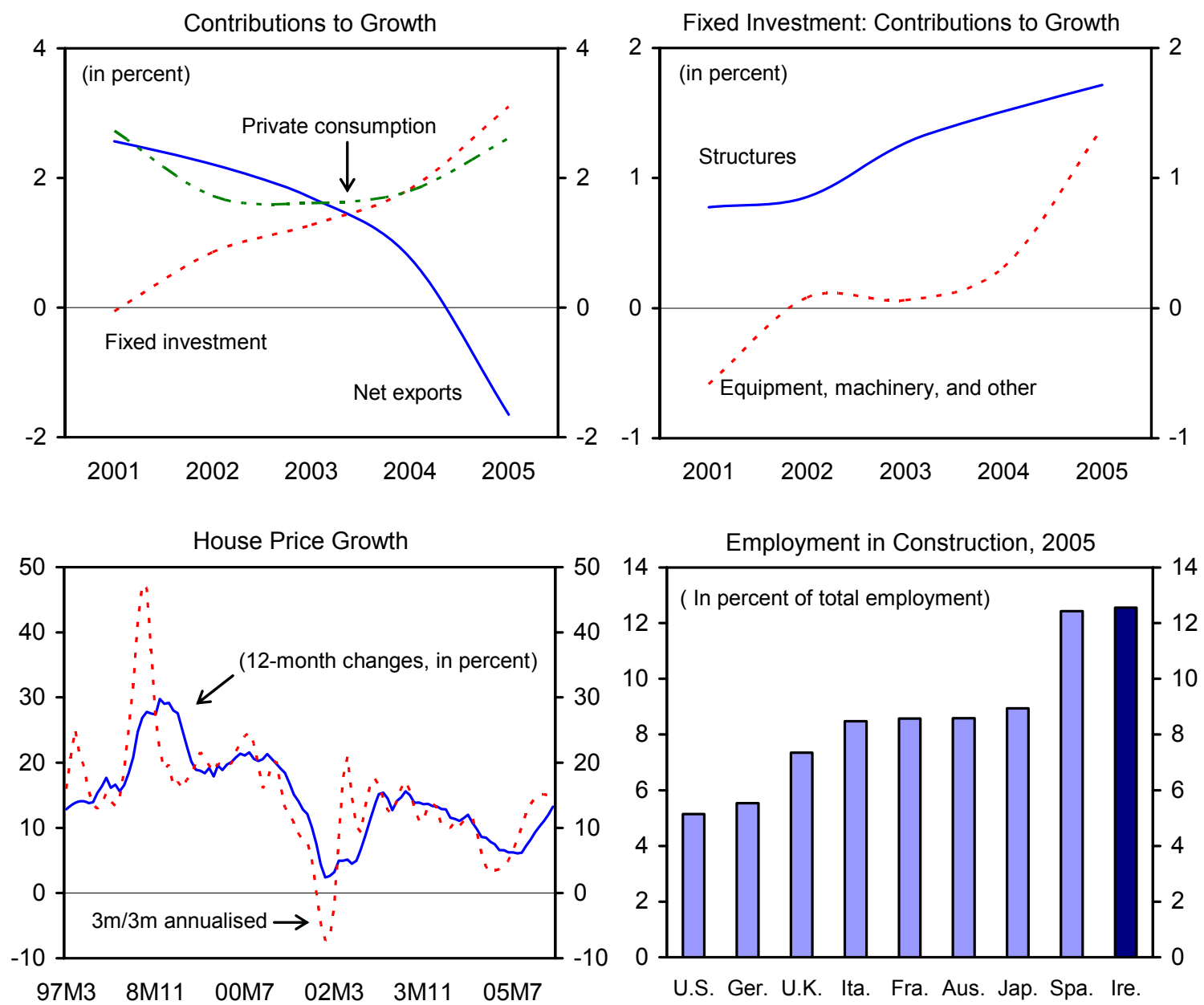

Private Sector Credit Growth


Sources: Central Bank of Ireland, Central Statistics Office, European Central Bank, Haver Analytics, and permanent tsb/ESRI. 
Figure 3. Eroding Competitiveness
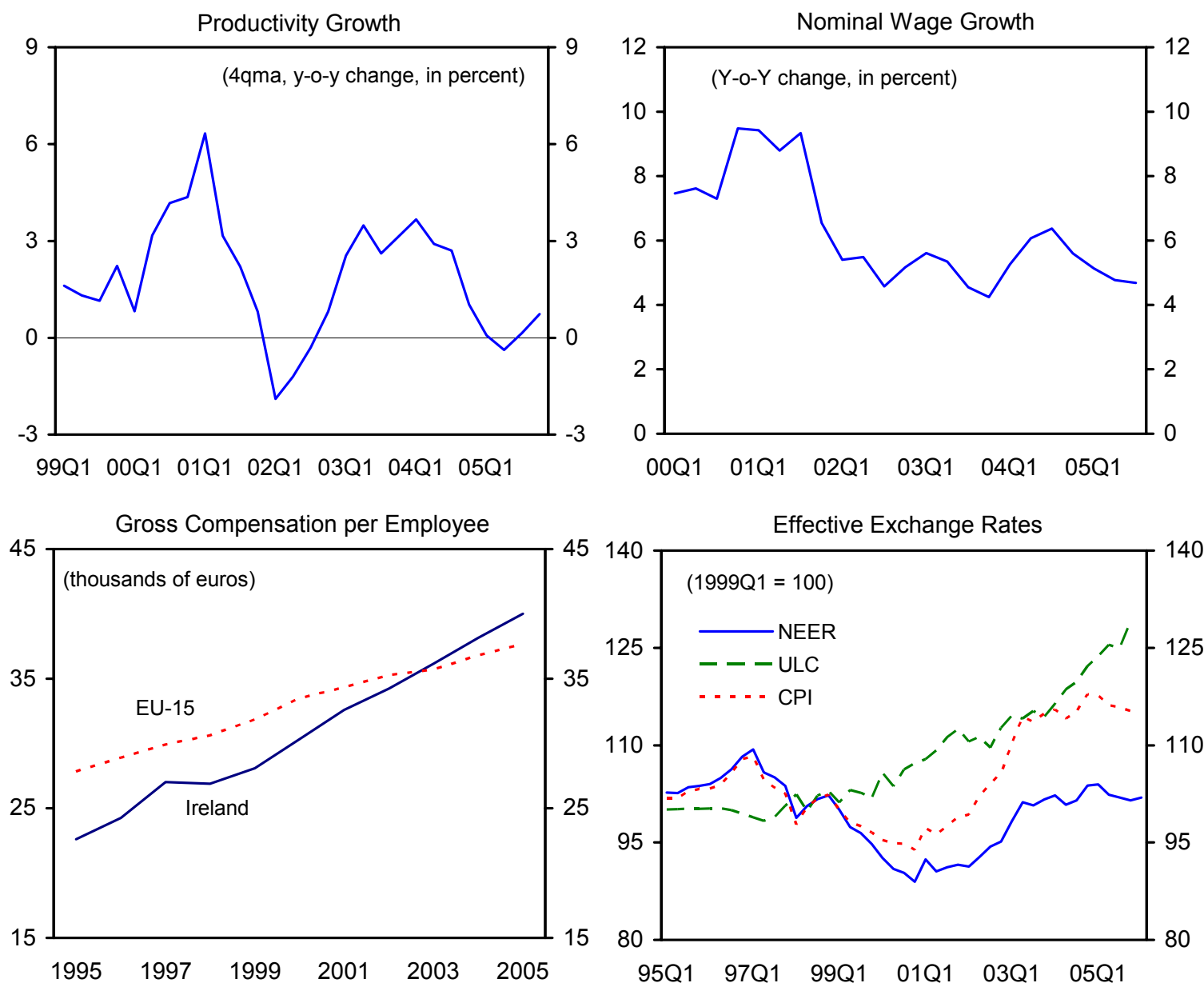

Ireland's Export Share

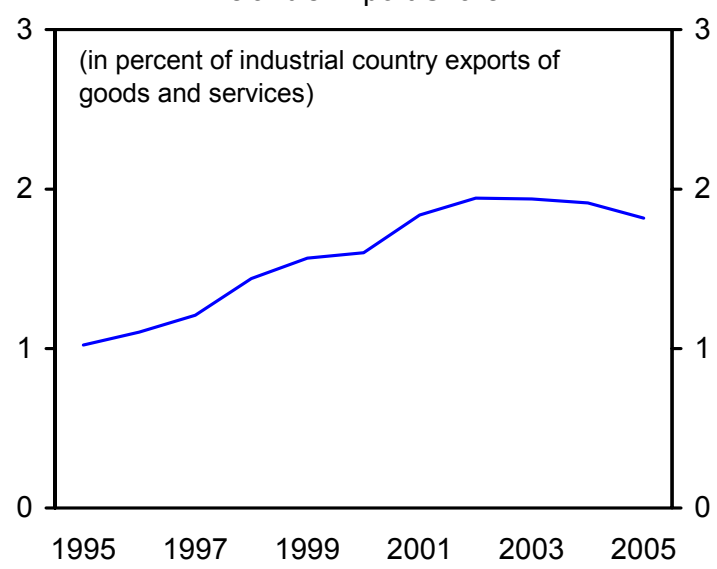

Current Account

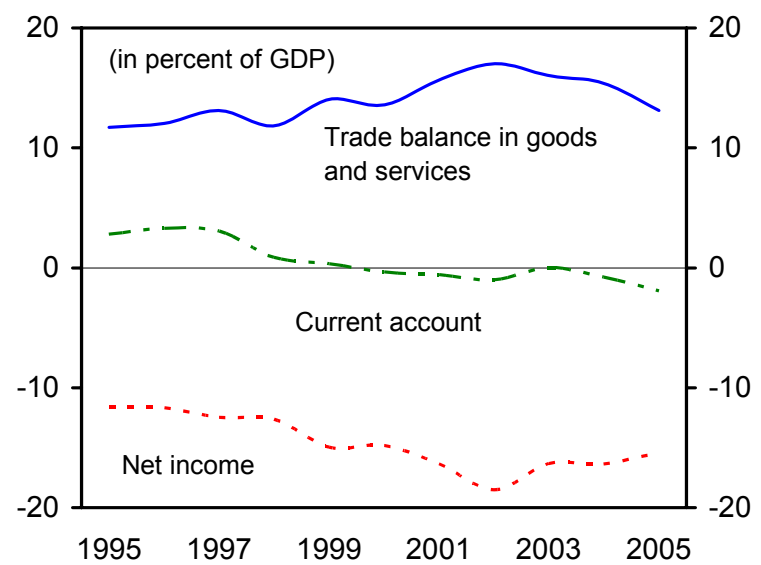

Sources: AMECO, Central Bank of Ireland, and Central Statistics Office, and IMF: World Economic Outlook. 
expand further in 2006 before reaching a plateau in 2007. Export growth is projected to increase, given rapid growth in partner countries and the reversal of the temporary weakness in the chemicals sector, and import growth to remain strong. HICP inflation is expected to fall back to 2 percent over the medium term, as the impact of higher energy prices fades. Officials at the Central Bank of Ireland (CBI) and the Department of Finance (DOF) gave broadly similar characterizations of the outlook.

Macroeconomic Projections

(Percentage change, unless otherwise indicated)

\begin{tabular}{lccccc}
\hline & 2003 & 2004 & 2005 & 2006 & 2007 \\
\hline Real GNP & 5.1 & 4.0 & 5.4 & 5.4 & 5.4 \\
Real GDP & 4.4 & 4.5 & 4.7 & 5.4 & 5.4 \\
Real domestic demand & 4.6 & 4.3 & 6.8 & 6.3 & 5.7 \\
$\quad$ Private consumption & 3.4 & 3.8 & 5.6 & 6.5 & 6.8 \\
$\quad$ Public consumption & 3.5 & 2.4 & 3.1 & 3.5 & 3.5 \\
$\quad$ Fixed investment & 5.6 & 8.0 & 13.1 & 7.1 & 4.8 \\
$\quad$ Structures & 7.9 & 9.1 & 9.8 & 6.9 & 3.7 \\
$\quad$ Residential investment & 14.8 & 12.9 & 7.0 & 5.5 & 0.0 \\
$\quad$ Non-residential investment & -0.9 & 3.4 & 14.3 & 9.1 & 9.1 \\
$\quad$ Equipment & 1.0 & 5.0 & 22.0 & 7.5 & 7.5 \\
Change in stocks 1/ & 0.5 & -0.3 & -0.4 & 0.1 & 0.0 \\
Net exports 1/ & 1.7 & 0.8 & -1.7 & 0.0 & 0.5 \\
Exports & 0.8 & 7.0 & 1.8 & 4.3 & 5.0 \\
Imports & -1.4 & 7.6 & 4.6 & 5.1 & 5.3 \\
$\quad$ & & & & & \\
Current account (in percent of GDP) & 0.0 & -0.8 & -1.9 & -3.2 & -3.5 \\
Consumer Prices (HICP) & 4.0 & 2.3 & 2.2 & 2.7 & 2.5 \\
Unemployment rate (in percent) & 4.7 & 4.5 & 4.3 & 4.3 & 4.2 \\
\hline I/Contibutions to growth
\end{tabular}

$1 /$ Contributions to growth

\section{Given the large construction} sector, the authorities and staff expected its share of economic activity to decline over the next few years (Table 2). With rapid population growth and a low number of dwellings per capita, the underlying demand for housing in Ireland is strong. Nevertheless, most estimates of the underlying demand are lower than the current pace of house completions. House prices are seen as somewhat overvalued by staff, becoming somewhat overvalued by CBI officials, and in line with fundamentals by DOF officials. However, since CBI and DOF officials and staff concurred that
Ratio of Average House Price to Gross Annual Rental Income

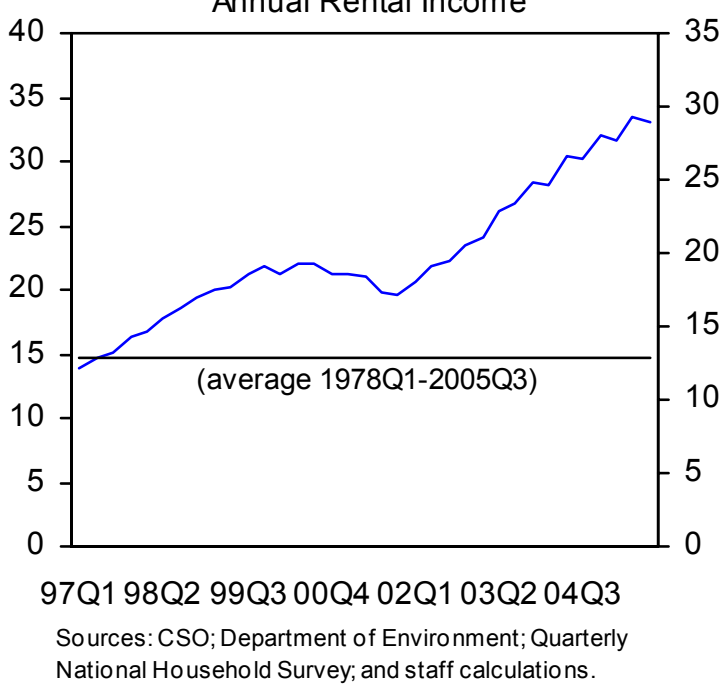


housing wealth effects on consumption in Ireland are small, all saw an abrupt contraction of the construction sector-which could occur without a fall in house prices - as the key risk.

\section{The authorities and staff concurred that rapid wage growth would undermine} competitiveness. Although there is no evidence of fundamental misalignment at present, the real effective exchange rate is slightly higher than most estimates of the equilibrium rate. Export market share is projected to continue its gentle decline, and the current account deficit to widen further (Table 3). As the unemployment rate is now in the vicinity of the natural rate, strong economic growth may lead to overheating. However, officials and staff recognized that strong net immigration will likely continue to dampen wage pressures and that labor productivity growth is likely to increase to about 2 percent, reflecting a combination of TFP growth, capital deepening, and improving educational attainment. In addition, officials noted that the pipeline of

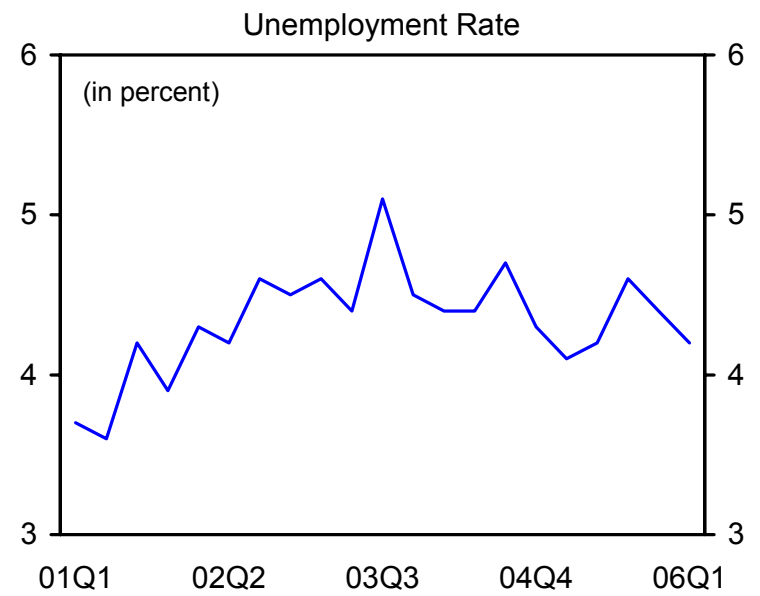
inward foreign direct investment remains healthy.

\section{The authorities and staff shared the view that, as a small open economy,} Ireland is vulnerable to external shocks. A disorderly unwinding of global imbalances could lead to a sharp appreciation of the euro, which would dampen export growth. A reversal of still benign global financial market conditions could lead to a deterioration of investor sentiment toward Ireland.

\section{With strong but unbalanced growth in prospect, the policy discussions focused} on the need to rebalance growth and prepare for the risk of a hard landing. Specifically:

- What are the risks to financial stability and how are they being addressed?

- How can fiscal policy help with rebalancing and preparing cushions?

- How are labor market policies supporting competitiveness?

\section{B. Financial Stability: Rapid Credit Growth Implies Risks}

\section{The Financial Sector Assessment Program (FSAP) Update found that the} financial system continues to perform well but rapid credit growth is a vulnerability (Table 4). Reflecting the strength of the economy, the banking system is well-capitalized and profitable, and nonperforming loans are low. However, rapid credit growth has led not only to a concentration of lending in property-related sectors, but has also increased banks' reliance on wholesale funding as lending growth has exceeded deposit growth. Officials observed that, while this has not given rise to exchange rate risk, as the funding is mostly 
euro-denominated, it is more expensive than retail funding and is likely to be affected more quickly by a change in international sentiment toward the Irish economy. Officials noted that an improved liquidity management framework for banks, in line with international best practice, would be implemented soon.
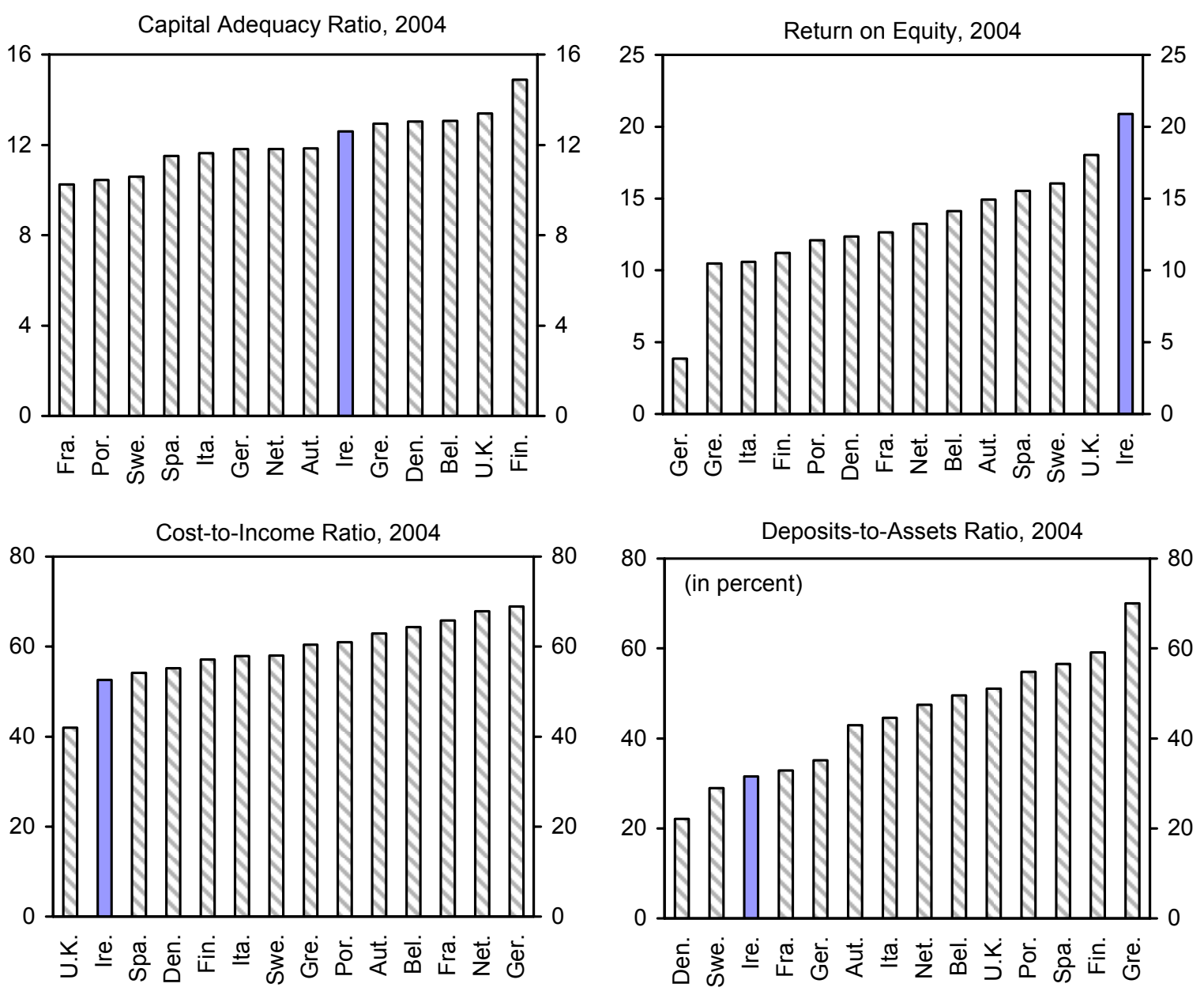

\section{Central Bank officials noted that recent stress tests indicate that the major}

lenders have adequate buffers to cover a range of shocks. The results suggest that, even in an extreme scenario involving a sharp rise in unemployment and a sharp decline in house prices, capital remains adequate in every bank. In addition, even a substantial withdrawal of private sector deposits would not exhaust the stock of liquid assets at any major lender, given banks' ample liquidity. Staff welcomed these favorable results, but observed that the long period of strong economic performance limits the ability to quantify the relationship between macroeconomic variables and credit risk. 
11. The Financial Regulator observed that the risk weighting on high loan-to-value mortgages was increased, consistent with the advice of the FSAP Update mission. High loan-to-value mortgages and interest-only mortgages became more prevalent in 2005 . While banks claim that the credit assessment procedures for these loans are robust and that access to these products is restricted to only the most creditworthy customers, their introduction coincided with survey results that suggested a relaxation of bank lending standards. In response, the Financial Regulator increased the risk weighting from 50 percent to 100 percent on the portion of each residential mortgage loan that exceeds 80 percent of the value of the property. Looking forward, officials and staff agreed that nonfinancial sector debt servicing costs are likely to rise further with continued rapid credit growth and the ongoing tightening cycle in ECB interest rates.

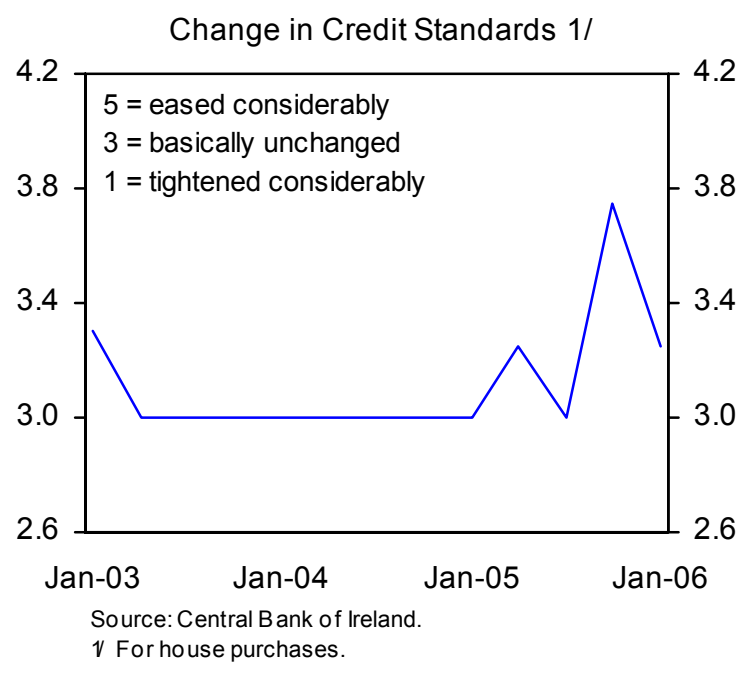

12. The FSAP Update found that the regulatory and supervisory framework has been strengthened in line with the recommendations of the 2000 FSAP. Supervision was unified in the Financial Regulator in 2003 and the regulatory regime for insurance was overhauled. The Financial Regulator has put in place a risk-based framework that aims to prioritize supervisory resources in a consistent manner across sectors based on risk profile and impact of default. Staff suggested several further improvements, notably in the insurance sector. The key priorities are to continue to strengthen the on-site supervision of insurers, especially regarding assessments of overall risk management and corporate governance practices, and to enhance public disclosure requirements for insurers in line with international best practice. The Financial Regulator agreed with staff's assessment and said that these recommendations would be implemented. In the near term, the insurance supervision department will be reorganized to enable more specialization and support a strengthening of on-site supervision. Staff also suggested that the authorities consider making the Prudential Director a member of the Board on par with the Consumer Director.

\section{Fiscal Policy: Preparing Cushions and Achieving Social Priorities}

\section{The general government fiscal position has been either close to balance or in} surplus for the past decade (Table 5). Combined with rapid economic growth, this has led to a sharp decline in the government debt ratio. In 2005, the general government recorded a surplus of 1 percent of GDP and staff's estimate of net debt fell to 18 percent of GDP. The fiscal outturn was considerably better than expected, mainly reflecting strong propertyrelated revenues. For the remainder of 2006, the authorities and staff agreed that budget 

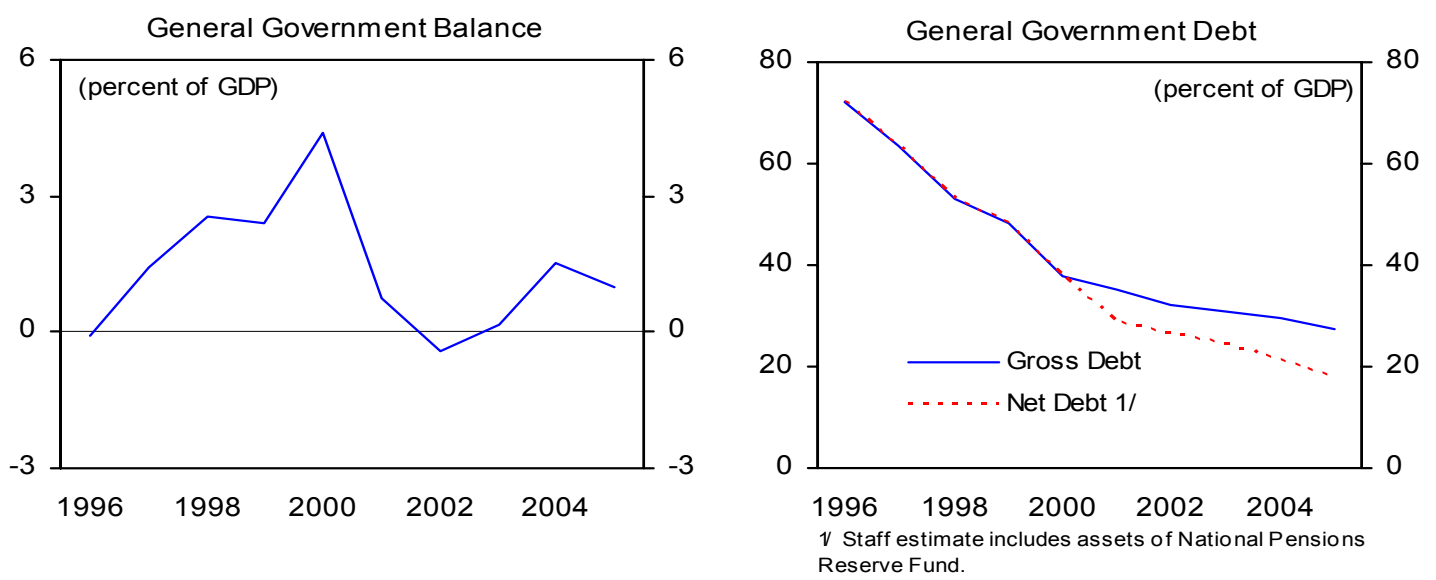

execution should remain prudent and that any windfall revenues should be saved. Given the likely overperformance of property-related revenues, officials and staff expected the fiscal balance in 2006 to be stronger than anticipated in the Budget. Staff project a surplus of $1 / 2$ percent of GDP.

\section{For 2007, staff called for modest fiscal tightening, in contrast to the substantial} loosening implicit in the authorities' projection. Given the likely outcome for 2006, staff observed that the Budget 2006 projection for 2007 would imply fiscal stimulus of more than 1 percentage point of GDP. Staff suggested that fiscal tightening of $1 / 2$ percentage point of GDP (implying a surplus of 1 percent of GDP in 2007) would be desirable in light of short-, medium-, and long-term considerations. In the short term, given Ireland's advanced cyclical position and still-accommodative euro area monetary policy, tighter fiscal policy is needed to dampen aggregate demand. Excess aggregate demand would give rise to wage pressures, which would undermine competitiveness. In the medium term, given the risk of a sharp fall in tax revenue due to either domestic or external shocks, a larger fiscal cushion is needed to allow automatic stabilizers to work fully in a possible downturn. During the 2000-02 downturn, the fiscal balance deteriorated by nearly 5 percentage points of GDP. In the long term, given that the projected rise in age-related spending through 2050 will be only partly

General Government Balances

(In percent of GDP)

\begin{tabular}{|c|c|c|c|c|c|c|}
\hline & 2003 & 2004 & 2005 & 2006 & 2007 & 2008 \\
\hline & \multicolumn{3}{|c|}{ Actual } & \multicolumn{3}{|c|}{ Projections } \\
\hline \multicolumn{7}{|l|}{ Overall balance } \\
\hline Budget 2006 & & & & -0.6 & -0.8 & -0.8 \\
\hline Staff projections $1 /$ & 0.2 & 1.5 & 1.0 & 0.5 & -0.6 & -0.6 \\
\hline
\end{tabular}

1/ Staff projections adjust the Budget 2006 projections for staff's macroeconomic and revenue buoyancy assumptions. 
offset by the National Pensions Reserve Fund and the eventual decline in government investment spending (as a share of GDP), greater pre-funding would allow for a smoother tax burden over time.
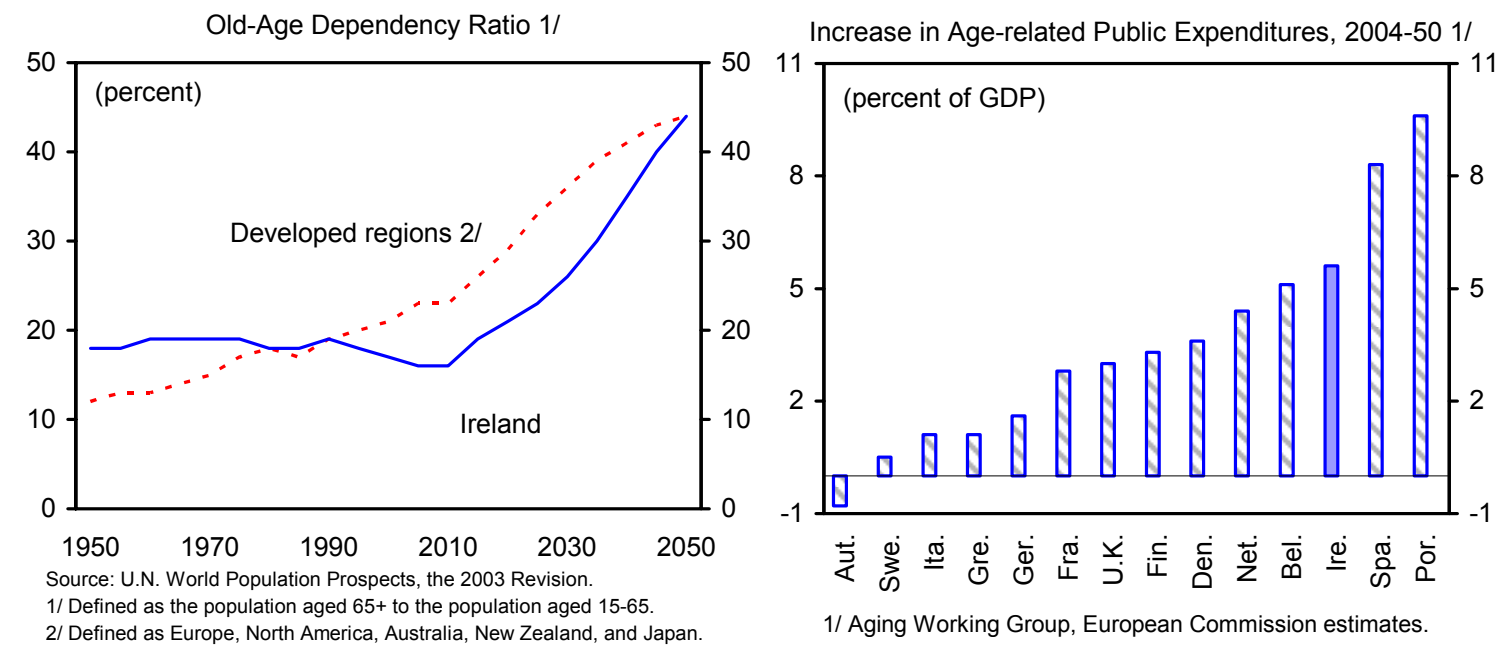

\section{The authorities acknowledged these arguments, but pointed to the need to}

achieve social priorities. Given Ireland's relatively low level of public capital, the authorities argued — and staff agreed - that a continued high level of government investment is appropriate for now. The authorities added that it is important to further improve public services, especially in the areas of education, health, and childcare, and that pressures would be especially intense in the run-up to general elections, due by mid-2007. The authorities agreed with staff, however, that the recent rapid increases in current spending had strained absorptive capacity and hence the growth rate of current spending needed to slow. On the revenue side, staff suggested broadening the tax base by phasing out the remaining propertybased incentive schemes, reducing mortgage interest tax relief, or introducing a property tax. Officials acknowledged the economic desirability of broadening the tax base, but pointed to popular opposition to

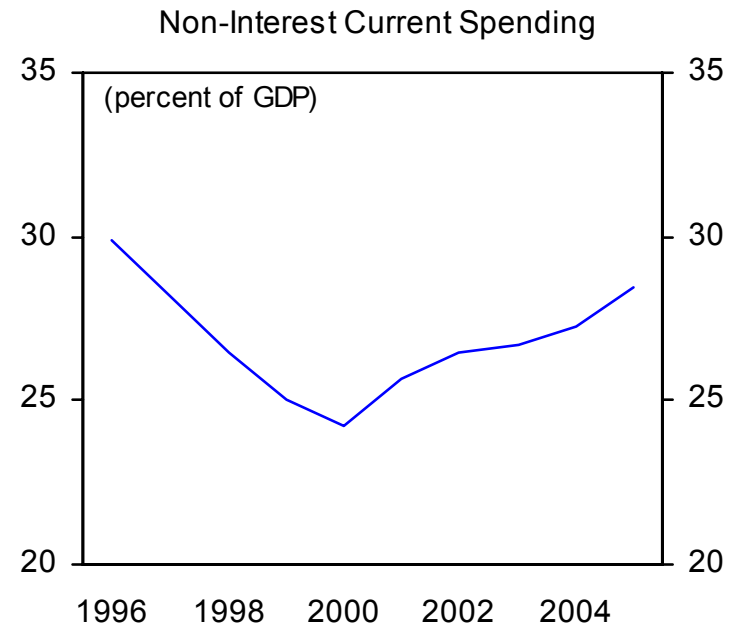
increasing property-related taxes.

\section{Staff welcomed the planned improvements in the fiscal framework. The} Department of Finance will publish an annual pre-budget report, with updated three-year economic and fiscal projections. Staff suggested that this report, along with the Budget, 
could underline the importance of countercyclical policy in the short term, of fiscal cushions to prepare for medium-term risks, and of increasing the pre-funding of age-related spending over the long term. Officials said that the DOF is enhancing its capacity to do long-term fiscal projections. In addition, spending departments will be required to prepare targets for outputs and to report on the fulfillment of those targets. Staff suggested that extending multi-year envelopes to current spending could help improve value for money in the delivery of public services. Finally, the Minister for Finance intends to meet annually with the parliamentary Finance and Public Services Committee to discuss the economic and fiscal outlook.

\section{Wage Policy: Flexibility and Competitiveness}

\section{The authorities and staff were concerned that the social partnership} negotiations underway at the time of the consultation discussions could undermine competitiveness. In the past, social partnership agreements (between labor unions, employers, and the government) have preserved peaceful labor relations, provided a useful vehicle for developing a common view of economic prospects, and established sensible guidelines for wage increases while allowing considerable flexibility at the firm level. There was agreement that - in order to contain Ireland's already high labor costs - prospective wage growth should be kept in line with the sum of projected productivity growth (about 2 percent)
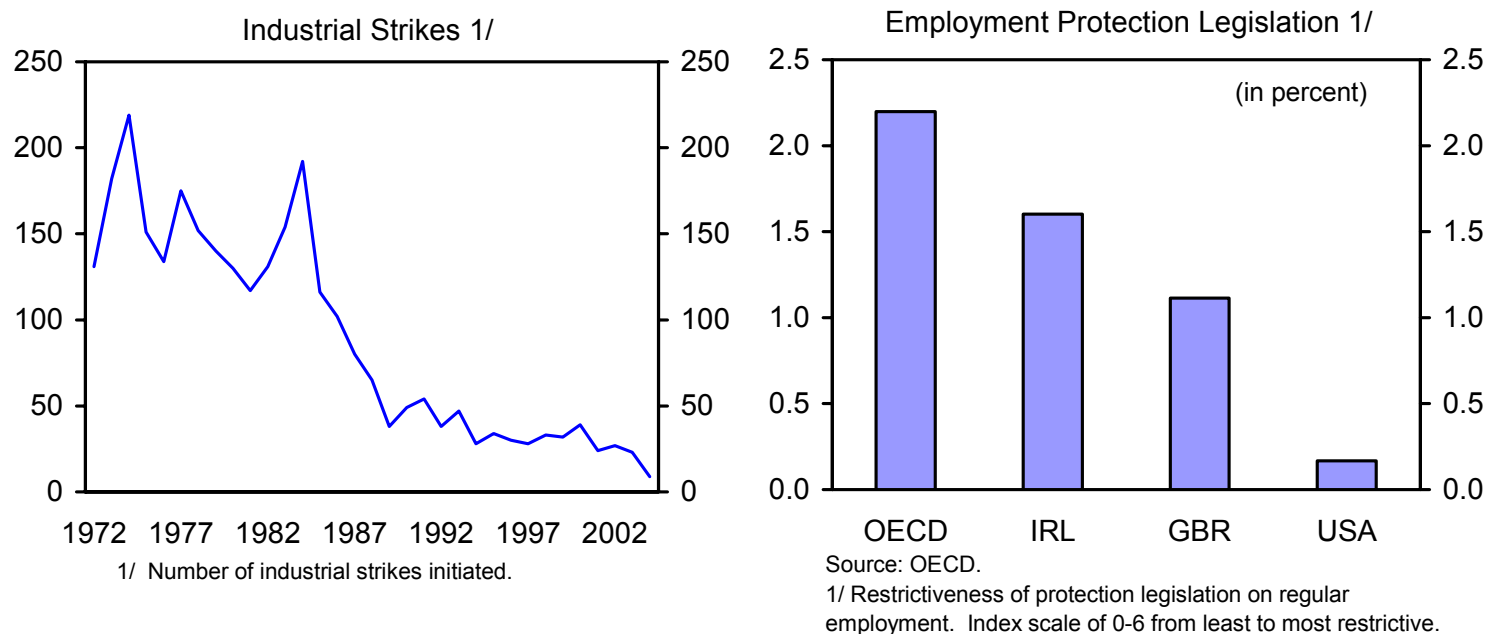

and inflation (about 2 percent). Staff noted that the recent increase in headline inflation was due to higher global energy prices and mortgage costs, which should not be allowed to feed into wage growth in Ireland. Given the likelihood that the partnership agreement would include some increase in firing costs, staff observed that employment protection legislation in Ireland is less restrictive than the OECD average, but more restrictive than in the UK or the US. DOF officials and business employers said that the circumstances under which the higher firing costs would apply are expected to be narrow, so there would be little impact on 
firms' ability to adjust labor input. After the consultation discussions concluded, the social partners reached a 27-month agreement that implies annual wage increases of about $4 \frac{1}{2}$ percent and some increase in firing costs.

\section{STAFF APPRAISAL}

18. Economic performance in Ireland continues to be impressive. In 2005, real GNP growth was the fastest in the EU15; the unemployment rate was among the lowest in industrial countries; and inflation was close to the euro area average. Ireland's robust performance has been supported by sound economic policies, including prudent fiscal policy, low taxes on labor and business income, and labor market flexibility.

\section{However, economic growth has become unbalanced, with heavy reliance on} building investment. House prices accelerated over the past year and may be somewhat overvalued. Bank credit has grown rapidly, especially to property-related sectors, and banks' reliance on wholesale funding - mainly from the euro area - has increased. At the same time, competitiveness has eroded, reflecting the combination of faster wage growth in Ireland compared to its trading partners, declining productivity growth, and the appreciation of the euro against the U.S. dollar.

\section{Looking ahead to 2006-07, economic growth will likely remain strong but} unbalanced. Domestic demand is projected to drive growth, with a continued gentle decline in export market share and a further widening of the current account deficit. Bank credit is expected to continue to expand rapidly, exacerbating financial sector risks. With the economy close to full employment, rapid growth may lead to overheating, which would put pressure on wages and further erode competitiveness. A contraction of the construction sector to a more sustainable size over the medium term is likely to be smooth, but an abrupt correction cannot be ruled out. In addition, Ireland is vulnerable to external shocks. Whatever the trigger, a hard landing would have adverse consequences for financial institutions and public finances. Recent stress tests indicate that the major lenders have adequate buffers to cover a range of shocks.

\section{The key task for financial supervision is to maintain the soundness of the}

financial system. The general approach of the Central Bank and the Financial Regulator is appropriate for the mature and sophisticated — but still relatively small—financial market. Stress tests should be done more frequently and the stress testing framework should continue to be upgraded. The increase in the risk weighting on high loan-to-value residential mortgages was an important signal of the need for banks to differentiate between higher- and lower-risk lending within an asset class. Looking forward, the Financial Regulator should continue to monitor banks' risk management practices, including for commercial property lending. The recent strengthening of the regulatory and supervisory framework is welcome and should continue, especially for insurance. 
22. Fiscal policy should be countercyclical and prudent. Given the strength of domestic demand, the risk of a hard landing, and the need to prepare for population aging, fiscal stimulus in 2007 would be unwarranted and modest tightening would be desirable. Slowing the growth of current spending to slightly below nominal GDP growth would help guard against the risk of inefficiencies, inherent in the rapid increases in spending in recent years. Improving public services is also a priority, but should be achieved by focusing on value for money, such as by monitoring government outputs and extending multi-year envelopes to current spending. The tax base could be broadened by phasing out the remaining property-based tax incentive schemes, reducing mortgage interest tax relief, or introducing a property tax. The authorities' plans to further improve the public debate on fiscal priorities are welcome.

\section{Continued wage moderation and labor market flexibility are essential to}

support competitiveness. The implementation of the recently-concluded social partnership agreement should continue to allow flexibility in wage increases at the firm level and minimize the increase in the restrictiveness of employment projection legislation.

24. It is proposed that the next Article IV consultation be held on the standard 12-month cycle. 
Table 1. Ireland: Selected Economic Indicators

(Annual change unless otherwise stated)

\begin{tabular}{|c|c|c|c|c|c|c|}
\hline & \multirow[b]{2}{*}{2002} & \multirow[b]{2}{*}{2003} & \multirow[b]{2}{*}{2004} & \multirow[b]{2}{*}{2005} & \multicolumn{2}{|c|}{ Proj. } \\
\hline & & & & & 2006 & 2007 \\
\hline \multicolumn{7}{|l|}{ National accounts (constant prices) } \\
\hline GNP & 2.7 & 5.1 & 4.0 & 5.4 & 5.4 & 5.4 \\
\hline GDP & 6.1 & 4.4 & 4.5 & 4.7 & 5.4 & 5.4 \\
\hline Domestic demand & 4.3 & 4.6 & 4.3 & 6.8 & 6.3 & 5.7 \\
\hline Private consumption & 3.5 & 3.4 & 3.8 & 5.6 & 6.5 & 6.8 \\
\hline Public consumption & 7.4 & 3.5 & 2.4 & 3.1 & 3.5 & 3.5 \\
\hline Gross fixed investment & 3.7 & 5.6 & 8.0 & 13.1 & 7.1 & 4.8 \\
\hline Net exports (contribution to GDP growth) & 2.2 & 1.7 & 0.8 & -1.7 & 0.0 & 0.5 \\
\hline Exports of goods and services & 4.0 & 0.8 & 7.0 & 1.8 & 4.3 & 5.0 \\
\hline Imports of goods and services & 1.8 & -1.4 & 7.6 & 4.6 & 5.1 & 5.3 \\
\hline \multicolumn{7}{|l|}{ Prices, wages and employment } \\
\hline Harmonized Index of Consumer Prices (annual average) & 4.7 & 4.0 & 2.3 & 2.2 & 2.7 & 2.5 \\
\hline Average hourly earnings, manufacturing & 8.6 & 4.7 & 4.5 & 3.6 & $\ldots$ & $\ldots$ \\
\hline Output, manufacturing $1 /$ & 7.6 & 4.6 & 0.4 & 3.1 & $\ldots$ & $\ldots$ \\
\hline Unit wage costs (manufacturing) $1 /$ & -7.6 & -2.4 & 0.9 & -0.2 & $\ldots$ & $\ldots$ \\
\hline GNP/employment & 0.9 & 3.2 & 1.0 & 0.7 & 1.3 & 1.8 \\
\hline Employment & 1.8 & 1.9 & 3.0 & 4.7 & 4.0 & 3.5 \\
\hline Unemployment rate (in percent) & 4.4 & 4.7 & 4.5 & 4.3 & 4.3 & 4.2 \\
\hline \multicolumn{7}{|l|}{ Money and credit (end-period) } \\
\hline M3 2/ & 9.3 & $\ldots$ & 22.5 & 19.8 & 19.7 & $\ldots$ \\
\hline Private sector credit $2 / 3 /$ & 15.0 & 17.9 & 26.6 & 28.8 & 29.6 & $\ldots$ \\
\hline \multicolumn{7}{|l|}{ Financial and asset markets (end-period) } \\
\hline Three-month treasury bill $2 /$ & 2.9 & 2.1 & 2.2 & 2.5 & 2.9 & $\ldots$ \\
\hline 10-year government bond 4/ & 4.3 & 4.6 & 3.7 & 3.3 & 4.0 & $\ldots$ \\
\hline ISEQ index 4/ & -18.8 & 12.2 & 26.8 & 16.8 & 20.8 & $\ldots$ \\
\hline House prices (permanent tsb index/ESRI) 2/ & 13.3 & 13.7 & 8.6 & 9.3 & 13.3 & $\ldots$ \\
\hline \multicolumn{7}{|l|}{ Public finance (In percent of GDP) } \\
\hline General government balance & -0.4 & 0.2 & 1.5 & 1.0 & 0.5 & -0.6 \\
\hline Primary balance & 0.9 & 1.4 & 2.7 & 2.2 & 1.6 & 0.6 \\
\hline General government debt & 32.0 & 31.0 & 29.4 & 27.6 & 26.2 & 26.2 \\
\hline \multicolumn{7}{|l|}{ External trade and balance of payments } \\
\hline Balance of goods and services (Percent of GDP) & 17.0 & 16.0 & 15.4 & 13.1 & 11.4 & 10.7 \\
\hline Current account (Percent of GDP) & -1.0 & 0.0 & -0.8 & -1.9 & -3.2 & -3.5 \\
\hline Official reserves (In billions of SDRs, end-period) & 4.0 & 2.8 & 1.9 & 0.6 & $\ldots$ & $\ldots$ \\
\hline \multicolumn{7}{|l|}{ Effective exchange rates $(1995=100$, annual average $)$} \\
\hline Nominal $5 /$ & 89.7 & 97.4 & 102.6 & 98.3 & 99.1 & $\ldots$ \\
\hline Real (CPI based) $5 /$ & 98.0 & 107.9 & 113.7 & 109.2 & 111.0 & $\ldots$ \\
\hline \multicolumn{7}{|l|}{ Memorandum items for 2005 : } \\
\hline Area & \multicolumn{6}{|c|}{70.3 thousand square kilometers } \\
\hline Population (in million) & \multicolumn{6}{|l|}{4.1} \\
\hline GDP per capita (in SDRs) & \multicolumn{6}{|l|}{32,035} \\
\hline
\end{tabular}

Sources: Department of Finance; Central Bank of Ireland; IMF, International Financial Statistics; and Fund staff calculations.

1/ Underlying productivity growth data may be overstated because of problems related to the measurement of output produced by multinational companies operating in Ireland.

2/ As of April 2006.

3/ Adjusted change, which includes the effects of transactions between credit institutions and non-bank international financial companies and valuation effects arising from exchange rate movements.

4/ As of May 2006.

5/ As of March 2006. 
Table 2. Ireland: Contributions to GDP Growth

(In percent) 1/

\begin{tabular}{lrrrrrr}
\hline & & & & & \multicolumn{2}{c}{ Proj. } \\
\cline { 6 - 8 } & 2002 & 2003 & 2004 & 2005 & 2006 & 2007 \\
\hline Domestic demand & 3.7 & 3.9 & 3.6 & 5.7 & 5.4 & 4.9 \\
Private consumption & 1.7 & 1.6 & 1.8 & 2.6 & 3.1 & 3.2 \\
Public consumption & 1.0 & 0.5 & 0.3 & 0.4 & 0.5 & 0.5 \\
Fixed investment & 0.9 & 1.3 & 1.8 & 3.1 & 1.8 & 1.3 \\
$\quad$ Structures & 0.9 & 1.3 & 1.5 & 1.7 & 1.3 & 0.7 \\
$\quad$ Residential investment & 0.5 & 1.3 & 1.3 & 0.8 & 0.6 & 0.0 \\
$\quad$ Equipment & 0.1 & 0.1 & 0.3 & 1.4 & 0.6 & 0.6 \\
Change in stocks & 0.1 & 0.5 & -0.3 & -0.4 & 0.1 & 0.0 \\
Net exports & 2.2 & 1.7 & 0.8 & -1.7 & 0.0 & 0.5 \\
Exports & 3.6 & 0.7 & 5.9 & 1.6 & 3.6 & 4.2 \\
Imports & -1.4 & 1.0 & -5.1 & -3.2 & -3.6 & -3.7 \\
Statistical discrepancy & 0.2 & -1.1 & 0.1 & 0.6 & 0.0 & 0.0 \\
GDP (annual percent change) & 6.1 & 4.4 & 4.5 & 4.7 & 5.4 & 5.4 \\
GNP (annual percent change) & 2.7 & 5.1 & 4.0 & 5.4 & 5.4 & 5.4 \\
\hline
\end{tabular}

Source: Fund staff estimates.

1/ Rounding may effect totals. 
Table 3. Ireland: Summary of Balance of Payments

\begin{tabular}{|c|c|c|c|c|c|c|c|c|c|}
\hline & \multirow[b]{2}{*}{2003} & \multirow[b]{2}{*}{2004} & \multirow[b]{2}{*}{2005} & \multicolumn{6}{|c|}{ Proj. } \\
\hline & & & & 2006 & 2007 & 2008 & 2009 & 2010 & 2011 \\
\hline & \multicolumn{9}{|c|}{ (In billions of euro) } \\
\hline Current account balance & 0.0 & -1.2 & -3.1 & -5.6 & -6.6 & -5.5 & -5.3 & -5.1 & -5.0 \\
\hline Balance of goods and services & 22.3 & 22.8 & 21.1 & 19.9 & 20.1 & 22.5 & 24.6 & 26.9 & 29.2 \\
\hline Goods balance & 30.3 & 29.4 & 27.6 & 29.0 & 29.2 & 30.4 & 31.8 & 33.6 & 35.7 \\
\hline Exports of goods & 78.3 & 80.2 & 82.8 & 87.6 & 89.8 & 94.0 & 98.5 & 103.7 & 109.6 \\
\hline Imports of goods & -48.0 & -50.9 & -55.2 & -58.6 & -60.6 & -63.6 & -66.7 & -70.1 & -73.9 \\
\hline Services balance & -8.0 & -6.5 & -6.6 & -9.2 & -9.0 & -8.0 & -7.1 & -6.7 & -6.5 \\
\hline Credit & 38.1 & 43.3 & 44.4 & 45.1 & 47.5 & 50.7 & 53.8 & 56.5 & 59.5 \\
\hline Debit & -46.1 & -49.8 & -51.0 & -54.3 & -56.5 & -58.6 & -60.9 & -63.3 & -66.0 \\
\hline \multicolumn{10}{|l|}{ Of which: Royalties } \\
\hline Credit & 0.2 & 0.2 & 0.2 & $\ldots$ & $\ldots$ & $\ldots$ & $\ldots$ & $\ldots$ & $\ldots$ \\
\hline Debit & -14.3 & -14.3 & -14.3 & $\ldots$ & $\ldots$ & $\ldots$ & $\ldots$ & $\ldots$ & $\ldots$ \\
\hline Income balance & -22.7 & -24.3 & -24.7 & -26.1 & -27.3 & -28.6 & -30.7 & -32.8 & -35.1 \\
\hline Credit & 30.1 & 33.8 & 40.6 & $\ldots$ & $\ldots$ & $\ldots$ & $\ldots$ & $\ldots$ & $\ldots$ \\
\hline Debit & -52.9 & -58.1 & -65.3 & $\ldots$ & $\ldots$ & $\ldots$ & $\ldots$ & $\ldots$ & $\ldots$ \\
\hline Current transfers (net) & 0.4 & 0.3 & 0.6 & 0.6 & 0.7 & 0.7 & 0.8 & 0.8 & 0.9 \\
\hline Capital and financial account balance & -1.3 & 5.8 & 3.4 & $\ldots$ & $\ldots$ & $\ldots$ & $\ldots$ & $\ldots$ & $\ldots$ \\
\hline Capital account balance & 0.1 & 0.4 & 0.3 & $\ldots$ & $\ldots$ & $\ldots$ & $\ldots$ & $\ldots$ & $\ldots$ \\
\hline Financial account & -1.4 & 5.4 & 3.1 & $\ldots$ & $\ldots$ & $\ldots$ & $\ldots$ & $\ldots$ & $\ldots$ \\
\hline Direct investment & 15.3 & -3.7 & -28.7 & $\ldots$ & $\ldots$ & $\ldots$ & $\ldots$ & $\ldots$ & $\ldots$ \\
\hline Portfolio investment & -40.0 & -5.7 & 44.4 & $\ldots$ & $\ldots$ & $\ldots$ & $\ldots$ & $\ldots$ & $\ldots$ \\
\hline Other investment & 21.6 & 13.7 & -14.0 & $\ldots$ & $\ldots$ & $\ldots$ & $\ldots$ & $\ldots$ & $\ldots$ \\
\hline Reserve assets & 1.8 & 1.2 & 1.5 & $\cdots$ & $\cdots$ & $\cdots$ & $\cdots$ & $\cdots$ & $\cdots$ \\
\hline \multirow[t]{2}{*}{ Net errors and omissions } & -1.3 & 4.7 & 0.4 & $\ldots$ & $\ldots$ & $\ldots$ & $\ldots$ & $\ldots$ & $\cdots$ \\
\hline & \multicolumn{9}{|c|}{ (In percent of GDP) } \\
\hline \multicolumn{10}{|l|}{ Memorandum items } \\
\hline Current account balance & 0.0 & -0.8 & -1.9 & -3.2 & -3.5 & -2.7 & -2.4 & -2.2 & -2.0 \\
\hline Balance on goods and services & 16.0 & 15.4 & 13.1 & 11.4 & 10.7 & 11.1 & 11.4 & 11.6 & 11.8 \\
\hline Goods balance & 21.8 & 19.8 & 17.2 & 16.7 & 15.6 & 15.0 & 14.7 & 14.5 & 14.4 \\
\hline Services balance & -5.8 & -4.4 & -4.1 & -5.3 & -4.8 & -3.9 & -3.3 & -2.9 & -2.6 \\
\hline Income balance & -16.3 & -16.4 & -15.4 & -15.0 & -14.6 & -14.2 & -14.2 & -14.2 & -14.2 \\
\hline Current transfers & 0.3 & 0.2 & 0.4 & 0.4 & 0.4 & 0.4 & 0.4 & 0.4 & 0.4 \\
\hline $\begin{array}{l}\text { Capital and financial account balance } \\
\text { Of which: }\end{array}$ & -0.9 & 3.9 & 2.1 & $\ldots$ & $\ldots$ & $\ldots$ & $\ldots$ & $\ldots$ & ... \\
\hline Direct Investment & 11.0 & -2.5 & -17.9 & $\ldots$ & $\ldots$ & $\ldots$ & $\ldots$ & $\ldots$ & $\ldots$ \\
\hline Portfolio Investment & -28.7 & -3.8 & 27.7 & $\ldots$ & $\ldots$ & $\ldots$ & $\ldots$ & $\ldots$ & $\ldots$ \\
\hline Other Investment & 15.5 & 9.2 & -8.7 & $\ldots$ & $\ldots$ & $\ldots$ & $\ldots$ & $\ldots$ & $\ldots$ \\
\hline
\end{tabular}

Sources: The Central Statistics Office; and Fund staff estimates. 
Table 4. Ireland: Indicators of External and Financial Vulnerability (In percent of GDP, unless otherwise indicated)

\begin{tabular}{|c|c|c|c|c|c|c|}
\hline & 2000 & 2001 & 2002 & 2003 & 2004 & 2005 \\
\hline \multicolumn{7}{|l|}{ External indicators } \\
\hline Exports (annual percent change, value in U.S. dollars) & 10.3 & 10.4 & 9.4 & 14.7 & 16.8 & 3.2 \\
\hline Imports (annual percent change, value in U.S. dollars) & 12.9 & 8.0 & 6.1 & 13.4 & 17.7 & 5.6 \\
\hline Terms of trade (goods, annual percent change) & -3.1 & 2.0 & 2.0 & -0.6 & -1.4 & 3.0 \\
\hline Current account balance & -0.4 & -0.6 & -1.0 & 0.0 & -0.8 & -1.9 \\
\hline & 0.3 & 1.2 & -0.9 & 3.9 & 2.1 \\
\hline Inward portfolio investment & 80.4 & 84.8 & 57.6 & 75.3 & 85.5 & 99.4 \\
\hline Inward foreign direct investment & 26.8 & 9.2 & 23.9 & 14.5 & 6.0 & -11.4 \\
\hline Other investment liabilities (net) & -8.7 & 16.3 & 14.8 & 15.5 & 9.2 & -8.7 \\
\hline Total external debt $1 /$ & 2.0 & 1.8 & 0.6 & 0.0 & 0.0 & 0.0 \\
\hline \multicolumn{7}{|l|}{ Of which: } \\
\hline External debt to exports ratio & 2.6 & 2.4 & 0.8 & 0.0 & 0.0 & 0.0 \\
\hline External interest payments to exports (in percent) & 0.2 & 0.1 & 0.2 & 0.0 & 0.0 & 0.0 \\
\hline U.S. dollar per euro (period average) & 0.92 & 0.89 & 0.94 & 1.13 & 1.24 & 1.24 \\
\hline \multicolumn{7}{|l|}{ Financial markets indicators } \\
\hline General government debt & 37.8 & 35.3 & 32.0 & 31.0 & 29.4 & 27.6 \\
\hline Government bond yield (10-year, end-period) & 5.1 & 5.1 & 4.3 & 4.3 & 3.7 & 3.3 \\
\hline Spread of government bond yield with Germany (end of period) & 0.2 & 0.6 & 0.2 & 0.3 & 0.3 & 0.0 \\
\hline Real government bond yield (10-year, period average, based on national $\mathrm{CPI}$ ) & -0.1 & 0.1 & 0.3 & 0.6 & 1.9 & 0.9 \\
\hline Annual change in ISEQ index (in percent, end of period) & 14.1 & -0.3 & -30.0 & 23.2 & 26.0 & 18.8 \\
\hline Personal lending interest rate & 11.8 & 10.6 & 10.4 & 9.9 & 9.9 & 10.1 \\
\hline Variable mortgage interest rate & 6.0 & 4.6 & 4.2 & 3.5 & 3.5 & 3.6 \\
\hline \multicolumn{7}{|l|}{ Financial sector risk indicators } \\
\hline Annual credit growth rates (to private sector) & 21.3 & 15.1 & 15.0 & 17.9 & 26.6 & 28.8 \\
\hline Annual deposit growth rates & 15.6 & 15.6 & 9.6 & 11.9 & 14.1 & 23.9 \\
\hline $\begin{array}{l}\text { Personal lending as a share of total loans } \\
\text { (excluding financial intermediation and government) } \\
\text { Of which: }\end{array}$ & 52.1 & 52.2 & 55.3 & 55.6 & 55.8 & 54.6 \\
\hline House mortgage finance & 39.0 & 38.8 & 42.4 & 44.4 & 44.9 & 44.6 \\
\hline Annual mortgage credit growth rates & 24.3 & 17.8 & 23.1 & 25.5 & 26.5 & 28.5 \\
\hline \multicolumn{7}{|l|}{ Commercial property lending as a percent of total loans } \\
\hline (excluding financial intermediation) $2 /$ & 15.0 & 16.4 & 17.0 & 19.7 & 21.2 & 25.3 \\
\hline Foreign-currency denominated assets (in percent of total assets) & 41.5 & 44.6 & 40.1 & 32.5 & 29.4 & 33.9 \\
\hline Foreign-currency denominated liabilities (in percent of total liabilities) & 44.4 & 47.4 & 42.9 & 34.2 & 32.2 & 35.9 \\
\hline Contingent and off-balance sheet accounts (in percent of total assets) $3 /$ & 465 & 592 & 505 & 538 & 662 & 879 \\
\hline Non-performing loans (in percent of total loans) 4 / & 1.03 & 1.03 & 0.97 & 0.93 & 0.82 & 0.68 \\
\hline Total provisions for loan losses (in percent of total loans) & 1.1 & 1.1 & 1.1 & 0.9 & 0.7 & 0.5 \\
\hline Risk-weighted capital/asset ratios of domestic banks (in percent) & 10.7 & 10.6 & 12.3 & 13.9 & 12.6 & 12.0 \\
\hline Bank return on assets & 1.2 & 0.9 & 1.0 & 0.9 & 1.0 & $\ldots$ \\
\hline Bank return on equity & 22.0 & 16.0 & 18.0 & 17.8 & 20.7 & $\ldots$ \\
\hline Liquid assets of all banks to total assets (liquid asset ratio) & 32.0 & 30.0 & 30.0 & 33.6 & 33.0 & 34.2 \\
\hline Liquid assets of all banks to short-term liabilities (in percent) & 44.0 & 37.0 & 34.0 & 41.2 & 40.0 & 40.1 \\
\hline Deposits to $\mathrm{M} 3$ ratio $5 / 6 /$ & 1.03 & 1.02 & 1.02 & 1.46 & 1.36 & 1.40 \\
\hline Loan-to-deposit ratio vis-à-vis Irish residents 2/ 7/ & 1.36 & 1.44 & 1.43 & 1.46 & 1.61 & 1.77 \\
\hline vis-à-vis total 2/ 7/ & 1.54 & 1.59 & 1.51 & 1.57 & 1.72 & 1.82 \\
\hline \multicolumn{7}{|l|}{ Concentration ratios in the banking sector } \\
\hline No. of banks accounting for 25 percent of total assets & 3.0 & 3.0 & 3.0 & 2.0 & 2.0 & 2.0 \\
\hline No. of banks accounting for 75 percent of total assets & 23.0 & 21.0 & 19.0 & 18.0 & 17.0 & 16.0 \\
\hline Share of state-owned banks in total assets & 2.0 & 1.0 & 0.0 & 0.0 & 0.0 & 0.0 \\
\hline Share of foreign-owned banks in total assets & 39.0 & 42.0 & 29.0 & 31.0 & 34.0 & 32.3 \\
\hline
\end{tabular}

Sources: Data provided by the authorities; Central Bank of Ireland; International Financial Statistics; Bloomberg; and Fund staff estimates.

1/ Represents non-euro debt of the government sector.

2/ Includes lending for construction and real estate activities.

3/ Credit equivalent values.

4/ Owing to differences in classification, international comparisons of nonperforming loans are indicative only.

5 / Non-government deposits vis-à-vis Irish and nonresidents to M3 ratio.

6/ The methodology used to compile M3 has been amended in line with Eurosystem requirements. Therefore, there is a break in the series.

7/ Nongovernment loans/nongovernment deposits ratio. 
Table 5. Ireland: General Government Finances (In percent of GDP)

\begin{tabular}{|c|c|c|c|c|c|c|}
\hline & \multicolumn{3}{|c|}{ Actual } & \multicolumn{3}{|c|}{ Staff Projections 1/ } \\
\hline & 2003 & 2004 & 2005 & 2006 & 2007 & 2008 \\
\hline Current balance & 3.9 & 4.7 & 4.1 & 4.5 & 3.8 & 4.0 \\
\hline Current revenue, of which: & 31.7 & 33.2 & 33.7 & 33.6 & 33.5 & 33.4 \\
\hline Tax revenue (including taxes on capital) & 24.2 & 25.4 & 25.8 & 25.7 & 25.6 & 25.6 \\
\hline Social security receipts & 4.2 & 4.4 & 4.5 & 4.5 & 4.5 & 4.5 \\
\hline Miscellaneous & 3.3 & 3.3 & 3.4 & 3.3 & 3.3 & 3.3 \\
\hline Current expenditure, of which: & 27.9 & 28.4 & 29.6 & 29.1 & 29.8 & 29.5 \\
\hline Interest payments & 1.2 & 1.2 & 1.2 & 1.2 & 1.2 & 1.2 \\
\hline Goods and services & 5.3 & 5.3 & 4.9 & 5.5 & 5.6 & 5.5 \\
\hline Compensation of employees & 9.0 & 9.3 & 9.9 & 9.2 & 9.5 & 9.5 \\
\hline Current transfers & 11.6 & 11.9 & 12.8 & 12.5 & 12.6 & 12.4 \\
\hline Depreciation & 0.8 & 0.8 & 0.8 & 0.8 & 0.8 & 0.8 \\
\hline Current expenditure, excluding interest & 26.7 & 27.3 & 28.4 & 28.0 & 28.6 & 28.2 \\
\hline Capital balance & -3.7 & -3.2 & -3.1 & -4.0 & -4.4 & -4.5 \\
\hline Capital receipts (excluding taxes on capital) & 1.1 & 1.1 & 0.9 & 0.9 & 0.8 & 0.8 \\
\hline Gross capital formation & 3.8 & 3.6 & 3.4 & 3.8 & 4.1 & 4.3 \\
\hline Capital transfers & 0.9 & 0.7 & 0.6 & 1.0 & 1.0 & 1.0 \\
\hline General government balance & 0.2 & 1.5 & 1.0 & 0.5 & -0.6 & -0.6 \\
\hline Primary balance & 1.4 & 2.7 & 2.2 & 1.6 & 0.6 & 0.7 \\
\hline \multicolumn{7}{|l|}{ Memorandum items: } \\
\hline \multicolumn{7}{|l|}{ Structural (as a percent of potential GDP) } \\
\hline Government balance (including one-off factors) & 0.4 & 1.8 & 1.0 & 0.3 & -0.9 & -0.6 \\
\hline Revenue & 32.8 & 34.3 & 34.6 & 34.4 & 34.3 & 34.2 \\
\hline Expenditure & 32.4 & 32.6 & 33.6 & 34.1 & 35.1 & 34.9 \\
\hline Government balance (excluding one-off factors) & 0.1 & 0.8 & 1.3 & 0.2 & -1.0 & -0.6 \\
\hline Primary balance & 1.6 & 3.0 & 2.2 & 1.5 & 0.3 & 0.6 \\
\hline General government gross debt (as percent of GDP) & 31.0 & 29.4 & 27.6 & 26.2 & 26.2 & 26.2 \\
\hline General government net debt (as percent of GDP) 2/ & 24.2 & 21.5 & 17.9 & 16.0 & 15.2 & 14.5 \\
\hline Output Gap & -0.4 & -0.5 & 0.0 & 0.4 & 0.6 & 0.2 \\
\hline Growth in nominal GDP & 6.6 & 6.8 & 7.9 & 8.4 & 7.8 & 7.8 \\
\hline
\end{tabular}

Sources: Department of Finance and staff estimates.

1/ Staff projections adjust the Budget 2006 projections for staff's macroeconomic and revenue buoyancy assumptions. 2/ Net debt is defined as gross debt minus the value of the National Pensions Reserve Fund. 
INTERNATIONAL MONETARY FUND

IRELAND

Staff Report for the 2006 Article IV Consultation

Supplementary Information

Prepared by the European Department

Approved by Susan Schadler and Michael Hadjimichael

July 18, 2006

This supplement contains updated staff report and PIN tables, reflecting revisions to historical national accounts and balance of payments data, as well as the first estimate of Q1 GDP and the latest public finance data. The revisions and new data do not change the thrust of the staff appraisal. The key changes to the tables are shown below.

Main Changes to Macroeconomic Projections

(Percent change, unless otherwise indicated)

\begin{tabular}{lcccccc}
\hline & \multicolumn{2}{c}{2005} & & \multicolumn{2}{c}{2006} \\
\cline { 2 - 3 } \cline { 5 - 6 } & Previous & Revised & & Previous & Revised \\
\hline GNP & 5.4 & 5.4 & & 5.4 & 6.2 \\
GDP & 4.7 & 5.5 & & 5.4 & 5.8 \\
Private Consumption & 5.6 & 6.6 & & 6.5 & 6.0 \\
$\quad$ Structures Investment & 9.8 & 10.4 & & 6.9 & 10.3 \\
Current account 1/ & -1.9 & -2.6 & & -3.2 & -3.0 \\
\hline
\end{tabular}

1/ In percent of GDP. 
Table 1. Ireland: Selected Economic Indicators

(Annual change unless otherwise stated)

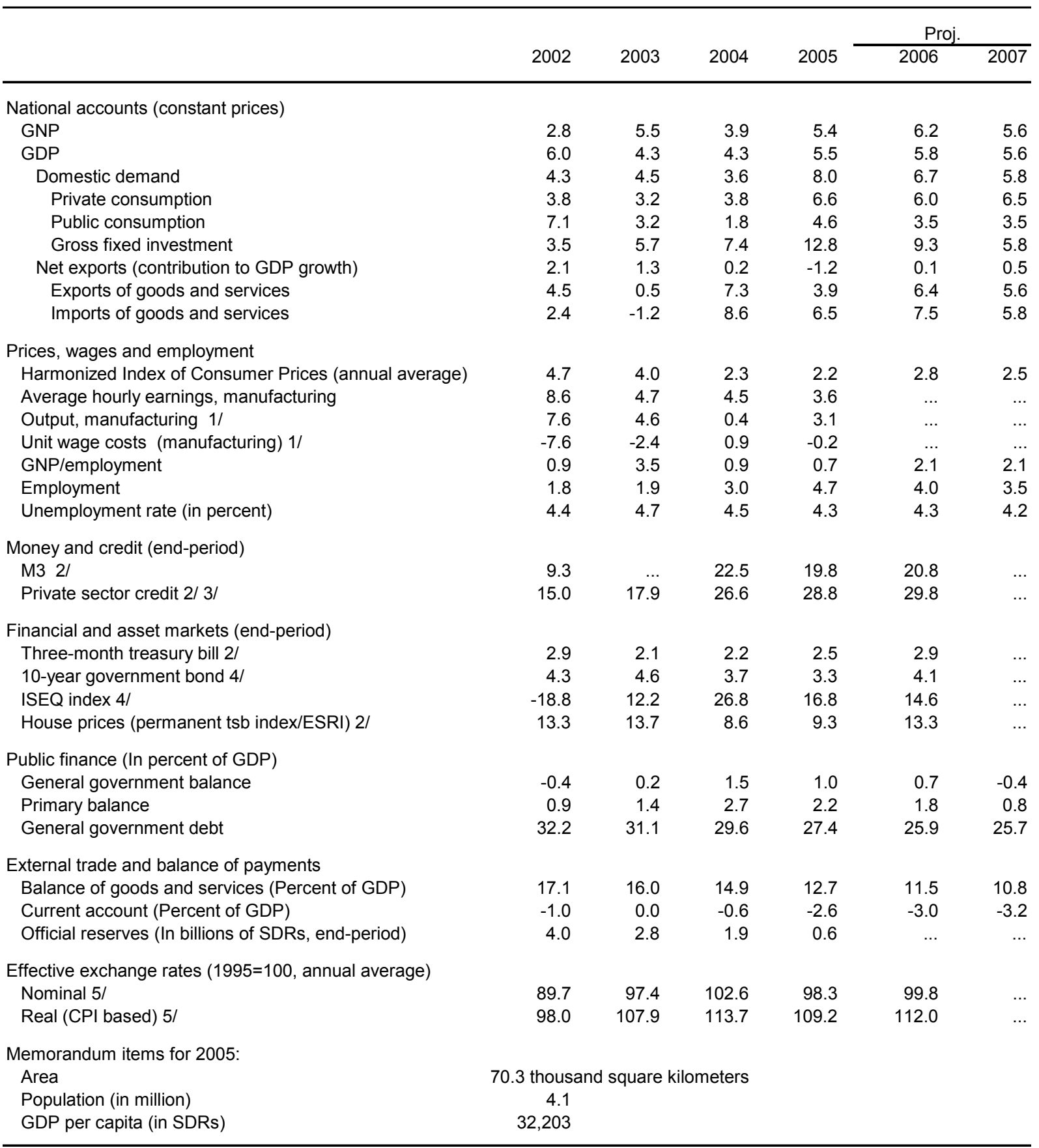

Sources: Department of Finance; Central Bank of Ireland; IMF, International Financial Statistics; and Fund staff calculations.

1/ Underlying productivity growth data may be overstated because of problems related to the measurement of output produced by multinational companies operating in Ireland.

2/ As of May 2006

3/ Adjusted change, which includes the effects of transactions between credit institutions and non-bank international financial companies and valuation effects arising from exchange rate movements.

4/ As of June 2006.

5/ As of April 2006. 
Table 2. Ireland: Contributions to GDP Growth

(In percent) 1/

\begin{tabular}{lrrrrrr}
\hline & & & & & \multicolumn{2}{c}{ Proj. } \\
\cline { 5 - 7 } & 2002 & 2003 & 2004 & 2005 & 2006 & 2007 \\
\hline Domestic demand & 3.8 & 3.8 & 3.1 & 6.8 & 5.8 & 5.1 \\
$\quad$ Private consumption & 1.8 & 1.5 & 1.8 & 3.1 & 2.8 & 3.1 \\
Public consumption & 1.0 & 0.5 & 0.3 & 0.7 & 0.5 & 0.5 \\
Fixed investment & 0.8 & 1.3 & 1.8 & 3.1 & 2.4 & 1.6 \\
$\quad$ Structures & 0.9 & 1.4 & 1.3 & 1.9 & 2.0 & 1.1 \\
$\quad$ Residential investment & 0.5 & 1.4 & 1.3 & 1.5 & 1.0 & 0.4 \\
$\quad$ Equipment & 0.0 & 0.0 & 0.5 & 1.2 & 0.5 & 0.5 \\
Change in stocks & 0.1 & 0.5 & -0.7 & -0.1 & 0.1 & 0.0 \\
Net exports & 2.1 & 1.3 & 0.2 & -1.2 & 0.1 & 0.5 \\
Exports & 3.9 & 0.5 & 6.0 & 3.3 & 5.3 & 4.6 \\
Imports & -1.8 & 0.9 & -5.7 & -4.5 & -5.2 & -4.1 \\
Statistical discrepancy & 0.1 & -0.9 & 1.0 & -0.1 & -0.1 & 0.0 \\
GDP (annual percent change) & 6.0 & 4.3 & 4.3 & 5.5 & 5.8 & 5.6 \\
GNP (annual percent change) & 2.8 & 5.5 & 3.9 & 5.4 & 6.2 & 5.6 \\
\hline
\end{tabular}

Source: Fund staff estimates.

1/ Rounding may effect totals. 
Table 3. Ireland: Summary of Balance of Payments

\begin{tabular}{|c|c|c|c|c|c|c|c|c|c|}
\hline & \multirow[b]{2}{*}{2003} & \multirow[b]{2}{*}{2004} & \multirow[b]{2}{*}{2005} & \multicolumn{6}{|c|}{ Proj. } \\
\hline & & & & 2006 & 2007 & 2008 & 2009 & 2010 & 2011 \\
\hline & \multicolumn{9}{|c|}{ (In billions of euro) } \\
\hline Current account balance & 0.0 & -0.9 & -4.2 & -5.2 & -6.1 & -4.7 & -4.2 & -3.7 & -3.3 \\
\hline Balance of goods and services & 22.3 & 22.0 & 20.4 & 20.2 & 20.5 & 23.1 & 25.5 & 28.1 & 30.6 \\
\hline Goods balance & 30.3 & 28.9 & 26.9 & 26.5 & 27.0 & 28.8 & 30.4 & 32.4 & 34.4 \\
\hline Exports of goods & 78.3 & 80.5 & 83.7 & 89.3 & 93.0 & 97.9 & 103.0 & 108.7 & 114.8 \\
\hline Imports of goods & -48.0 & -51.6 & -56.8 & -62.8 & -66.0 & -69.2 & -72.6 & -76.2 & -80.5 \\
\hline Services balance & -8.0 & -7.0 & -6.4 & -6.4 & -6.5 & -5.7 & -4.9 & -4.4 & -3.8 \\
\hline Credit & 38.1 & 43.5 & 47.3 & 52.5 & 54.4 & 57.6 & 60.8 & 63.9 & 67.4 \\
\hline Debit & -46.1 & -50.5 & -53.7 & -58.8 & -61.0 & -63.2 & -65.7 & -68.3 & -71.2 \\
\hline \multicolumn{10}{|l|}{ Of which: Royalties } \\
\hline Credit & 0.2 & 0.2 & 0.2 & $\ldots$ & $\ldots$ & $\ldots$ & $\ldots$ & $\ldots$ & $\ldots$ \\
\hline Debit & -14.3 & -14.3 & -14.3 & .. & $\ldots$ & $\ldots$ & $\ldots$ & $\ldots$ & $\ldots$ \\
\hline Income balance & -21.7 & -23.2 & -25.1 & -26.0 & -27.3 & -28.5 & -30.5 & -32.6 & -34.8 \\
\hline Credit & 30.1 & 35.0 & 43.4 & $\ldots$ & $\ldots$ & $\ldots$ & $\ldots$ & $\ldots$ & $\ldots$ \\
\hline Debit & -51.9 & -58.2 & -68.6 & $\ldots$ & $\ldots$ & $\ldots$ & $\ldots$ & $\ldots$ & $\ldots$ \\
\hline Current transfers (net) & 0.4 & 0.3 & 0.6 & 0.6 & 0.7 & 0.7 & 0.8 & 0.8 & 0.9 \\
\hline Capital and financial account balance & -1.3 & 4.1 & -0.7 & $\ldots$ & $\ldots$ & $\ldots$ & $\ldots$ & $\ldots$ & $\ldots$ \\
\hline Capital account balance & 0.1 & 0.3 & 0.3 & $\ldots$ & $\ldots$ & $\ldots$ & $\ldots$ & $\ldots$ & $\ldots$ \\
\hline Financial account & -1.4 & 3.8 & -1.0 & $\ldots$ & $\ldots$ & $\ldots$ & $\ldots$ & $\ldots$ & $\ldots$ \\
\hline Direct investment & 15.3 & -23.1 & -35.9 & $\ldots$ & $\ldots$ & $\ldots$ & $\ldots$ & $\ldots$ & $\ldots$ \\
\hline Portfolio investment & -40.0 & 14.3 & 53.6 & $\ldots$ & $\ldots$ & $\ldots$ & $\ldots$ & $\ldots$ & $\ldots$ \\
\hline Other investment & 21.6 & 11.4 & -20.0 & $\ldots$ & $\ldots$ & $\ldots$ & $\ldots$ & $\ldots$ & $\ldots$ \\
\hline Reserve assets & 1.8 & 1.2 & 1.5 & $\ldots$ & $\ldots$ & $\cdots$ & $\ldots$ & $\ldots$ & $\ldots$ \\
\hline Net errors and omissions & -1.3 & 3.2 & -4.9 & $\ldots$ & $\ldots$ & $\ldots$ & $\ldots$ & $\ldots$ & $\ldots$ \\
\hline & \multicolumn{9}{|c|}{ (In percent of GDP) } \\
\hline \multicolumn{10}{|l|}{ Memorandum items } \\
\hline Current account balance & 0.0 & -0.6 & -2.6 & -3.0 & -3.2 & -2.3 & -1.9 & -1.6 & -1.3 \\
\hline Balance on goods and services & 16.0 & 14.9 & 12.7 & 11.5 & 10.8 & 11.4 & 11.7 & 12.1 & 12.3 \\
\hline Goods balance & 21.8 & 19.6 & 16.7 & 15.2 & 14.3 & 14.1 & 14.0 & 14.0 & 13.9 \\
\hline Services balance & -5.8 & -4.7 & -4.0 & -3.6 & -3.5 & -2.8 & -2.3 & -1.9 & -1.5 \\
\hline Income balance & -15.6 & -15.7 & -15.6 & -14.9 & -14.5 & -14.0 & -14.0 & -14.0 & -14.0 \\
\hline Current transfers & 0.3 & 0.2 & 0.4 & 0.4 & 0.4 & 0.4 & 0.4 & 0.4 & 0.4 \\
\hline $\begin{array}{l}\text { Capital and financial account balance } \\
\text { Of which: }\end{array}$ & -0.9 & 2.8 & -0.4 & $\ldots$ & $\ldots$ & $\ldots$ & $\ldots$ & $\ldots$ & $\ldots$ \\
\hline Direct Investment & 11.0 & -15.7 & -22.3 & $\ldots$ & $\ldots$ & $\ldots$ & $\ldots$ & $\ldots$ & $\ldots$ \\
\hline Portfolio Investment & -28.8 & 9.7 & 33.2 & $\ldots$ & $\ldots$ & $\ldots$ & $\ldots$ & $\ldots$ & $\ldots$ \\
\hline Other Investment & 15.5 & 7.7 & -12.4 & $\ldots$ & $\ldots$ & $\ldots$ & $\ldots$ & $\ldots$ & $\ldots$ \\
\hline
\end{tabular}

Sources: The Central Statistics Office; and Fund staff estimates. 
Table 4. Ireland: Indicators of External and Financial Vulnerability (In percent of GDP, unless otherwise indicated)

\begin{tabular}{|c|c|c|c|c|c|c|}
\hline & 2000 & 2001 & 2002 & 2003 & 2004 & 2005 \\
\hline \multicolumn{7}{|l|}{ External indicators } \\
\hline Exports (annual percent change, value in U.S. dollars) & 10.3 & 10.4 & 9.4 & 14.7 & 17.3 & 5.8 \\
\hline Imports (annual percent change, value in U.S. dollars) & 12.9 & 8.0 & 6.1 & 13.4 & 19.4 & 8.5 \\
\hline Terms of trade (goods, annual percent change) & -3.1 & 2.0 & 2.0 & -0.6 & -1.4 & 3.0 \\
\hline Current account balance & -0.4 & -0.6 & -1.0 & 0.0 & -0.6 & -2.6 \\
\hline \multicolumn{6}{|l|}{ Of which: } & -0.4 \\
\hline Inward portfolio investment & 80.2 & 85.1 & 57.8 & 75.4 & 101.2 & 106.8 \\
\hline Inward foreign direct investment & 26.8 & 9.2 & 24.0 & 14.5 & -5.8 & -15.5 \\
\hline Other investment liabilities (net) & -8.6 & 16.3 & 14.8 & 15.5 & 7.7 & -12.4 \\
\hline Total external debt $1 /$ & 2.0 & 1.8 & 0.6 & 0.0 & 0.0 & 0.0 \\
\hline \multicolumn{7}{|l|}{ Of which: } \\
\hline External debt to exports ratio & 2.6 & 2.4 & 0.8 & 0.0 & 0.0 & 0.0 \\
\hline External interest payments to exports (in percent) & 0.2 & 0.1 & 0.2 & 0.0 & 0.0 & 0.0 \\
\hline U.S. dollar per euro (period average) & 0.92 & 0.89 & 0.94 & 1.13 & 1.24 & 1.24 \\
\hline U.K. $£$ per euro (period average) & 0.61 & 0.62 & 0.63 & 0.69 & 0.68 & 0.68 \\
\hline \multicolumn{7}{|l|}{ Financial markets indicators } \\
\hline General government debt & 37.8 & 35.4 & 32.2 & 31.1 & 29.6 & 27.4 \\
\hline Government bond yield (10-year, end-period) & 5.1 & 5.1 & 4.3 & 4.3 & 3.7 & 3.3 \\
\hline Spread of government bond yield with Germany (end of period) & 0.2 & 0.6 & 0.2 & 0.3 & 0.3 & 0.0 \\
\hline Real government bond yield (10-year, period average, based on national CPI) & -0.1 & 0.1 & 0.3 & 0.6 & 1.9 & 0.9 \\
\hline Annual change in ISEQ index (in percent, end of period) & 14.1 & -0.3 & -30.0 & 23.2 & 26.0 & 18.8 \\
\hline Personal lending interest rate & 11.8 & 10.6 & 10.4 & 9.9 & 9.9 & 10.1 \\
\hline Variable mortgage interest rate & 6.0 & 4.6 & 4.2 & 3.5 & 3.5 & 3.6 \\
\hline \multicolumn{7}{|l|}{ Financial sector risk indicators } \\
\hline Annual credit growth rates (to private sector) & 21.3 & 15.1 & 15.0 & 17.9 & 26.6 & 28.8 \\
\hline Annual deposit growth rates & 15.6 & 15.6 & 9.6 & 11.9 & 14.1 & 23.9 \\
\hline $\begin{array}{l}\text { Personal lending as a share of total loans } \\
\text { (excluding financial intermediation and government) }\end{array}$ & 52.1 & 52.2 & 55.3 & 55.6 & 55.8 & 54.6 \\
\hline \multicolumn{7}{|l|}{ Of which: } \\
\hline House mortgage finance & 39.0 & 38.8 & 42.4 & 44.4 & 44.9 & 44.6 \\
\hline Other housing finance & 1.0 & 0.9 & 0.8 & 0.4 & 0.3 & 0.3 \\
\hline Other personal lending & 12.2 & 12.5 & 12.0 & 10.8 & 10.6 & 9.7 \\
\hline Annual mortgage credit growth rates & 24.3 & 17.8 & 23.1 & 25.5 & 26.5 & 28.5 \\
\hline \multicolumn{7}{|l|}{ Commercial property lending as a percent of total loans } \\
\hline (excluding financial intermediation) $2 /$ & 15.0 & 16.4 & 17.0 & 19.7 & 21.2 & 25.3 \\
\hline Foreign-currency denominated assets (in percent of total assets) & 41.5 & 44.6 & 40.1 & 32.5 & 29.4 & 33.9 \\
\hline Foreign-currency denominated liabilities (in percent of total liabilities) & 44.4 & 47.4 & 42.9 & 34.2 & 32.2 & 35.9 \\
\hline Contingent and off-balance sheet accounts (in percent of total assets) $3 /$ & 465 & 592 & 505 & 538 & 662 & 879 \\
\hline Non-performing loans (in percent of total loans) 4/ & 1.03 & 1.03 & 0.97 & 0.93 & 0.82 & 0.68 \\
\hline Total provisions for loan losses (in percent of total loans) & 1.1 & 1.1 & 1.1 & 0.9 & 0.7 & 0.5 \\
\hline Risk-weighted capital/asset ratios of domestic banks (in percent) & 10.7 & 10.6 & 12.3 & 13.9 & 12.6 & 12.0 \\
\hline Bank return on assets & 1.2 & 0.9 & 1.0 & 0.9 & 1.0 & $\ldots$ \\
\hline Bank return on equity & 22.0 & 16.0 & 18.0 & 17.8 & 20.7 & $\cdots$ \\
\hline Liquid assets of all banks to total assets (liquid asset ratio) & 32.0 & 30.0 & 30.0 & 33.6 & 33.0 & 34.2 \\
\hline Liquid assets of all banks to short-term liabilities (in percent) & 44.0 & 37.0 & 34.0 & 41.2 & 40.0 & 40.1 \\
\hline Deposits to M3 ratio 5/ 6/ & 1.03 & 1.02 & 1.02 & 1.46 & 1.36 & 1.40 \\
\hline Loan-to-deposit ratio vis-à-vis Irish residents $2 / 7 /$ & 1.36 & 1.44 & 1.43 & 1.46 & 1.61 & 1.77 \\
\hline vis-à-vis total $2 / 7 /$ & 1.54 & 1.59 & 1.51 & 1.57 & 1.72 & 1.82 \\
\hline \multicolumn{7}{|l|}{ Concentration ratios in the banking sector } \\
\hline No. of banks accounting for 25 percent of total assets & 3.0 & 3.0 & 3.0 & 2.0 & 2.0 & 2.0 \\
\hline No. of banks accounting for 75 percent of total assets & 23.0 & 21.0 & 19.0 & 18.0 & 17.0 & 16.0 \\
\hline Share of state-owned banks in total assets & 2.0 & 1.0 & 0.0 & 0.0 & 0.0 & 0.0 \\
\hline Share of foreign-owned banks in total assets & 39.0 & 42.0 & 29.0 & 31.0 & 34.0 & 32.3 \\
\hline
\end{tabular}

Sources: Data provided by the authorities; Central Bank of Ireland; International Financial Statistics; Bloomberg; and Fund staff estimates.

1/ Represents non-euro debt of the government sector.

2/ Includes lending for construction and real estate activities.

3/ Credit equivalent values.

4/ Owing to differences in classification, international comparisons of nonperforming loans are indicative only.

5/ Non-government deposits vis-à-vis Irish and nonresidents to M3 ratio.

6/ The methodology used to compile M3 has been amended in line with Eurosystem requirements. Therefore, there is a break in the series.

7/ Nongovernment loans/nongovernment deposits ratio. 
Table 5. Ireland: General Government Finances

(In percent of GDP)

\begin{tabular}{|c|c|c|c|c|c|c|}
\hline & \multicolumn{3}{|c|}{ Actual } & \multicolumn{3}{|c|}{ Staff Projections 1/ } \\
\hline & 2003 & 2004 & 2005 & 2006 & 2007 & 2008 \\
\hline Current balance & 3.9 & 4.8 & 4.0 & 4.7 & 4.0 & 4.1 \\
\hline Current revenue, of which: & 31.8 & 33.4 & 33.5 & 33.7 & 33.5 & 33.4 \\
\hline Tax revenue (including taxes on capital) & 24.2 & 25.6 & 25.7 & 25.8 & 25.7 & 25.6 \\
\hline Social security receipts & 4.2 & 4.4 & 4.5 & 4.5 & 4.5 & 4.5 \\
\hline Miscellaneous & 3.3 & 3.4 & 3.3 & 3.3 & 3.3 & 3.3 \\
\hline Current expenditure, of which: & 27.9 & 28.6 & 29.4 & 29.0 & 29.6 & 29.3 \\
\hline Interest payments & 1.2 & 1.2 & 1.2 & 1.2 & 1.2 & 1.2 \\
\hline Goods and services & 5.3 & 5.3 & 4.9 & 5.4 & 5.5 & 5.5 \\
\hline Compensation of employees & 9.0 & 9.4 & 9.9 & 9.2 & 9.5 & 9.5 \\
\hline Current transfers & 11.7 & 11.9 & 12.7 & 12.4 & 12.5 & 12.3 \\
\hline Depreciation & 0.8 & 0.8 & 0.8 & 0.8 & 0.8 & 0.8 \\
\hline Current expenditure, excluding interest & 26.7 & 27.4 & 28.3 & 27.9 & 28.4 & 28.1 \\
\hline Capital balance & -3.7 & -3.2 & -3.0 & -4.0 & -4.4 & -4.5 \\
\hline Capital receipts (excluding taxes on capital) & 1.1 & 1.2 & 0.9 & 0.9 & 0.8 & 0.8 \\
\hline Gross capital formation & 3.8 & 3.6 & 3.4 & 3.8 & 4.1 & 4.3 \\
\hline Capital transfers & 0.9 & 0.8 & 0.6 & 1.0 & 1.0 & 1.0 \\
\hline General government balance & 0.2 & 1.5 & 1.0 & 0.7 & -0.4 & -0.5 \\
\hline Primary balance & 1.4 & 2.7 & 2.2 & 1.8 & 0.8 & 0.8 \\
\hline \multicolumn{7}{|l|}{ Memorandum items: } \\
\hline \multicolumn{7}{|l|}{ Structural (as a percent of potential GDP) } \\
\hline Government balance (including one-off factors) & 0.4 & 1.9 & 1.0 & 0.5 & -0.7 & -0.5 \\
\hline Revenue & 32.8 & 34.6 & 34.4 & 34.5 & 34.3 & 34.2 \\
\hline Expenditure & 32.5 & 32.7 & 33.4 & 34.0 & 35.0 & 34.7 \\
\hline Government balance (excluding one-off factors) & 0.0 & 1.0 & 1.3 & 0.4 & -0.8 & -0.5 \\
\hline Primary balance & 1.6 & 3.1 & 2.2 & 1.7 & 0.5 & 0.7 \\
\hline General government gross debt (as percent of GDP) & 31.1 & 29.6 & 27.4 & 25.9 & 25.7 & 25.6 \\
\hline General government net debt (as percent of GDP) $2 /$ & 24.2 & 21.6 & 17.9 & 15.7 & 14.8 & 14.0 \\
\hline Output Gap & -0.3 & -0.8 & 0.0 & 0.4 & 0.6 & 0.2 \\
\hline Growth in nominal GDP & 6.9 & 6.2 & 9.2 & 8.3 & 8.1 & 7.7 \\
\hline
\end{tabular}

Sources: Department of Finance and staff estimates.

1/ Staff projections are based on the 2006 budget, adjusted for staff's macroeconomic and revenue buoyancy assumptions.

2/ Net debt is defined as gross debt minus the value of the National Pensions Reserve Fund. 


\section{Real Economy (change in percent)}

\section{Real GDP}

Real GNP

Domestic demand

Exports of goods and services

Imports of goods and services

HICP

Unemployment rate (in percent)

Public Finances (percent of GDP)

General government balance

Structural balance 2/

General government debt

Money and Credit (end-period, percent change)

M3 3/

Private sector credit 4/

Interest rates (end-period)

Three-month

10-year government bond yield

Balance of Payments (percent of GDP)

Trade balance (goods and services)

Current account

Reserves (gold valued at SDR 35 per ounce

end of period, in billions of SDRs)

\section{Exchange Rate}

Exchange rate regime

Present rate (July 17, 2006)

Nominal effective rate $(1995=100)$

Real effective rate $(1995=100$, CPI based $)$
6.0

4.3

4.3

5.5

5.8

2.8

5.5

3.9

5.4

6.2

4.3

4.5

3.6

8.0

6.7

4.5

0.5

7.3

3.9

6.4

$2.4 \quad-1.2$

8.6

6.5

7.5

4.7

4.0

2.3

2.2

2.8

4.4

4.7

4.5

4.3

4.3

$\begin{array}{ccccc}-0.4 & 0.2 & 1.5 & 1.0 & 0.7 \\ -1.3 & 0.4 & 1.9 & 1.0 & 0.5 \\ 32.2 & 31.1 & 29.6 & 27.4 & 25.9\end{array}$

$\begin{array}{llllll}9.3 & \ldots & 22.5 & 19.8 & 20.8 & 5 /\end{array}$

$\begin{array}{llllll}15.0 & 17.9 & 26.6 & 28.8 & 29.8 & 5 /\end{array}$

$\begin{array}{llllll}2.9 & 2.1 & 2.2 & 2.5 & 2.9 & 5 / \\ 4.3 & 4.6 & 3.7 & 3.3 & 4.1 & 6 /\end{array}$

$\begin{array}{lllll}17.1 & 16.0 & 14.9 & 12.7 & 11.5\end{array}$

$\begin{array}{lllll}-1.0 & 0.0 & -0.6 & -2.6 & -3.0\end{array}$

$\begin{array}{llll}4.0 & 2.8 & 1.9 & 0.6\end{array}$

Member of euro area

US\$ per euro 1.2541

$\begin{array}{cccccc}89.7 & 97.4 & 102.6 & 98.3 & 99.8 & 7 / \\ 98.0 & 107.9 & 113.7 & 109.2 & 112.0 & 7 /\end{array}$

Sources: Central Statistics Office; Department of Finance, Datastream and IMF International

Financial Statistics.

1/ Staff projections, except where noted.

2/ In percent of potential GDP.

3/ The methodology used to compile M3 has been amended in line with Eurosystem requirements.

Therefore, there is a break in the series.

4/ Adjusted change, which includes the effects of transactions between credit institutions and non-bank international financial companies and valuation effects arising from exchange rate movements.

5/ As of May 2006.

6/ As of June 2006.

7/ As of April 2006. 


\section{INTERNATIONAL MONETARY FUND}

\section{Public Information Notice}

EXTERNAL

RELATIONS DEPARTMENT
Public Information Notice (PIN) No. 06/88 FOR IMMEDIATE RELEASE August 7, 2006
International Monetary Fund $70019^{\text {th }}$ Street, NW

Washington, D. C. 20431 USA

\section{IMF Executive Board Concludes 2006 Article IV Consultation with Ireland}

On July 26, 2006, the Executive Board of the International Monetary Fund (IMF) concluded the Article IV consultation with Ireland. ${ }^{1}$

\section{Background}

Ireland's economic performance remains strong. In recent years, real GNP growth was one of the highest among industrial countries; the unemployment rate was among the lowest; and HICP inflation declined to close to the euro area average. Employment growth was rapid, reflecting strong immigration and rising labor force participation. This remarkable performance reflected both good policies and fortunate circumstances. Prudent government spending led to declining government debt; low taxes on labor and business income encouraged labor supply and investment; and flexible labor and product markets helped growth. At the same time, favorable demographics boosted the working-age population, and participation in EMU lowered interest rates.

\footnotetext{
${ }^{1}$ Under Article IV of the IMF's Articles of Agreement, the IMF holds bilateral discussions with members, usually every year. A staff team visits the country, collects economic and financial information, and discusses with officials the country's economic developments and policies. On return to headquarters, the staff prepares a report, which forms the basis for discussion by the Executive Board. At the conclusion of the discussion, the Managing Director, as Chairman of the Board, summarizes the views of Executive Directors, and this summary is transmitted to the country's authorities.
} 
However, economic activity has become reliant on building investment and competitiveness has eroded. The share of the construction sector in economic activity has increased and is now one of the highest in Europe. Bank credit to property-related sectors has grown rapidly and now accounts for more than half of total bank lending. Household debt as a share of household disposable income rose to about 130 percent in 2005, among the highest in Europe. Reflecting the expansion of the labor-intensive construction and services sectors, labor productivity growth has declined. The combination of the slowdown in productivity growth, faster wage growth in Ireland compared to its trading partners, and the appreciation of the euro, has led to an appreciation of the ULC-based real effective exchange rate. Partly as a result, the contribution of net exports to growth has fallen steadily since 2001 . After being in balance for several years, the external current account registered a deficit of about $2 \frac{1}{2}$ percent of GDP in 2005.

\section{Executive Board Assessment}

The Executive Directors commended Ireland's continued impressive economic performance, which has been supported by sound policies, including prudent fiscal policy, low taxes on labor and business income, and labor market flexibility. Economic growth is strong, unemployment is low and labor participation rising, and government debt has been reduced dramatically over the past two decades. Nevertheless, Directors observed that growth has become increasingly unbalanced in recent years, with heavy reliance on building investment, sharp increases in house prices, and rapid credit growth, especially to property-related sectors. At the same time, competitiveness has eroded, reflecting the combination of faster wage growth in Ireland compared to its trading partners, declining productivity growth, and the appreciation of the euro against the U.S. dollar. Directors observed that Ireland's small, highly open economy is also vulnerable to external shocks.

Directors expected economic growth in 2006-07 to remain strong, driven by domestic demand and accompanied by a widening current account deficit and continued rapid credit growth. While the contraction of the construction sector to a more sustainable size over the medium term is likely to be smooth, Directors noted that an abrupt correction cannot be ruled out.

Directors welcomed the Financial System Stability Assessment Update, which finds that Ireland's financial sector soundness indicators are generally strong and that the major lenders have adequate buffers to cover a range of shocks. The recent increase in the riskweighting on high loan-to-value residential mortgages is an important signal of the need for banks to differentiate between higher- and lower-risk lending within an asset class.

Directors suggested that the Financial Regulator continue to monitor banks' risk management practices, including for commercial property lending. Going forward, they called for continued updating of the stress-testing framework, and further strengthening of the regulatory and supervisory framework, especially for insurance. 
While recognizing that Ireland's fiscal position is sound, most Directors considered that a modest fiscal tightening would be desirable in 2007, given the strength of domestic demand, potential risks of a hard landing, and the need to prepare for population aging. Slowing the growth of current spending to slightly below nominal GDP growth would also help prevent inefficiencies that could otherwise emerge given the rapid increases in spending in recent years. A number of Directors, however, saw less merit in fiscal tightening at the current juncture, pointing to the need for further increases in spending to achieve social goals, as well as to the recent tightening of euro area monetary policy. Directors agreed that improvements in public services remain a key priority, and, in this context, encouraged the authorities to focus on value for money, including by monitoring government outputs and extending multi-year envelopes to current spending. They welcomed the authorities' plans to further deepen the public debate on fiscal priorities.

Directors considered that continued wage moderation and labor market flexibility are essential to support competitiveness. The implementation of the new social partnership agreement should continue to allow flexibility in wage increases at the firm level and minimize the increase in the restrictiveness of employment protection legislation.

Public Information Notices (PINs) form part of the IMF's efforts to promote transparency of the IMF's views and analysis of economic developments and policies. With the consent of the country (or countries) concerned, PINs are issued after Executive Board discussions of Article IV consultations with member countries, of its surveillance of developments at the regional level, of post-program monitoring, and of ex post assessments of member countries with longer-term program engagements. PINs are also issued after Executive Board discussions of general policy matters, unless otherwise decided by the Executive Board in a particular case. The Staff Report for the 2006 Article IV Consultation with Ireland is also available. 
Ireland: Selected Economic Indicators

$2002 \quad 2003 \quad 2004 \quad 2005 \quad 2006 \quad 1 /$

Real Economy (change in percent)

$\begin{array}{lrrrrr}\text { Real GDP } & 6.0 & 4.3 & 4.3 & 5.5 & 5.8 \\ \text { Real GNP } & 2.8 & 5.5 & 3.9 & 5.4 & 6.2 \\ \text { Domestic demand } & 4.3 & 4.5 & 3.6 & 8.0 & 6.7 \\ \text { Exports of goods and services } & 4.5 & 0.5 & 7.3 & 3.9 & 6.4 \\ \text { Imports of goods and services } & 2.4 & -1.2 & 8.6 & 6.5 & 7.5 \\ \text { HICP } & 4.7 & 4.0 & 2.3 & 2.2 & 2.8 \\ \text { Unemployment rate (in percent) } & 4.4 & 4.7 & 4.5 & 4.3 & 4.3\end{array}$

Public Finances (percent of GDP)

General government balance

Structural balance 2/

$\begin{array}{lllll}-0.4 & 0.2 & 1.5 & 1.0 & 0.7\end{array}$

$\begin{array}{lllll}-1.3 & 0.4 & 1.9 & 1.0 & 0.5\end{array}$

General government debt

$\begin{array}{lllll}32.2 & 31.1 & 29.6 & 27.4 & 25.9\end{array}$

Money and Credit (end-period, percent change)

M3 3/

Private sector credit 4/

$\begin{array}{rrrrrr}9.3 & \ldots & 22.5 & 19.8 & 20.8 & 5 / \\ 15.0 & 17.9 & 26.6 & 28.8 & 29.8 & 5 /\end{array}$

Interest Rates (end-period)

Three-month

10-year government bond yield

$\begin{array}{llllll}2.9 & 2.1 & 2.2 & 2.5 & 2.9 & 5 /\end{array}$

Balance of Payments (percent of GDP)

Trade balance (goods and services)

Current account

$\begin{array}{lllll}17.1 & 16.0 & 14.9 & 12.7 & 11.5\end{array}$

$\begin{array}{lllll}-1.0 & 0.0 & -0.6 & -2.6 & -3.0\end{array}$

Reserves (gold valued at SDR 35 per ounce end of period, in billions of SDRs)

$\begin{array}{llll}4.0 & 2.8 & 1.9 & 0.6\end{array}$

\section{Exchange Rate}

Exchange rate regime

Present rate (July 17, 2006)

Member of euro area

US\$ per euro 1.2541

Nominal effective rate $(1995=100)$

Real effective rate $(1995=100, \mathrm{CPI}$ based)

$89.7 \quad 97.4 \quad 102.6$

$\begin{array}{lllllll}98.0 & 107.9 & 113.7 & 109.2 & 112.0 & 7 /\end{array}$

Sources: Central Statistics Office; Department of Finance, Datastream and IMF International Financial Statistics.

1/ Staff projections, except where noted.

2/ In percent of potential GDP.

3/ The methodology used to compile M3 has been amended in line with Eurosystem requirements. Therefore, there is a break in the series.

4/ Adjusted change, which includes the effects of transactions between credit institutions and nonbank international financial companies and valuation effects arising from exchange rate movements.

5/ As of May 2006.

6/ As of June 2006.

7/ As of April 2006. 